\title{
Numerically Based Proposals for the Stiffness and Strength of Masonry Infills with Openings in Reinforced Concrete Frames
}

\author{
Farhad Akhoundi ${ }^{1}$, Paulo B. Lourenço ${ }^{2}$, Graça Vasconcelos ${ }^{3}$
}

\begin{abstract}
Aimed at investigating the effect of openings on the in-plane behaviour of masonry infills in reinforced concrete frames, a parametric study is presented based on model calibration via experimental tests. Two types of openings are investigated: central window openings and different combinations of door and window openings based on the typologies of southern European countries. First, a finite element model of the structure is made using the DIANA software program. Then, after calibration with experimental results, a parametric analysis is carried out to investigate the effect of the presence and location of the different types of openings on the in-plane behaviour of the infilled frame. Finally, different equations for predicting the initial stiffness and lateral strength of infilled frames with any types of openings were obtained. An $\alpha$ factor related to the geometry of the piers between openings is proposed to take into account the location of the openings in the developed equations. Subsequently, the masonry infill panel is replaced by a diagonal strut. An empirical equation is also proposed for the width of an equivalent strut to replace a masonry infill panel with openings in such a way that they possess the same initial stiffness.
\end{abstract}

\section{Keywords:}

Masonry infills, reinforced concrete frames, opening, in-plane behaviour, numerical analysis, equivalent strut

\section{Introduction}

Specific masonry characteristics, such as ease of construction and long term performance, have been responsible for its widespread use in building construction for many centuries. Nowadays, masonry is typically employed in most modern buildings in the form of partition walls in reinforced concrete frames. Although masonry infills are often not considered in building design, their contribution to the in-plane behaviour of the masonry-infilled reinforced concrete frames is significant. This contribution can have a positive or negative effect, where "positive" means that the presence of the masonry infill improves the capacity of the structure to resist lateral loads, such as earthquakes. In other words, the composite system (masonry-infilled RC frame) might resist an earthquake, whereas a weak frame would not. As shown in Figure 1, the negative influence of infills is related mainly to the formation of short columns or a soft storey, which can lead to global or local failure of the structure. The formation of a short column occurs when masonry infills leave a short portion of the column clear, leading to column shear collapse. Although a soft storey is typically observed when the distribution of the infill walls along the height of the structure is irregular, the mechanism can also appear even in cases of a uniform distribution when: a) the ground motion is strong compared to design demand; b) the global ductility of the bare frame and structural elements is low; c) the infill walls are relatively weak and brittle, as discussed in detail in [1]. Although the infill panels are considered nonstructural elements, their damage or collapse is not desirable, given the consequences in terms

\footnotetext{
1 PhD Student, ISISE, University of Minho, Department of Civil Engineering, Azurém, 4800-058 Guimarães, Portugal, farhad.akhoundi@civil.uminho.pt

2 Professor, ISISE, University of Minho, Department of Civil Engineering, Azurém, 4800-058 Guimarães, Portugal, pbl@civil.uminho.pt

3 Assistant Professor, ISISE, University of Minho, Department of Civil Engineering, Azurém, 4800-058 Guimarães, Portugal,graca@civil.uminho.pt
} 
of loss of human life and repair or reconstruction costs. In addition, such damage can limit occupancy immediately after an earthquake event.

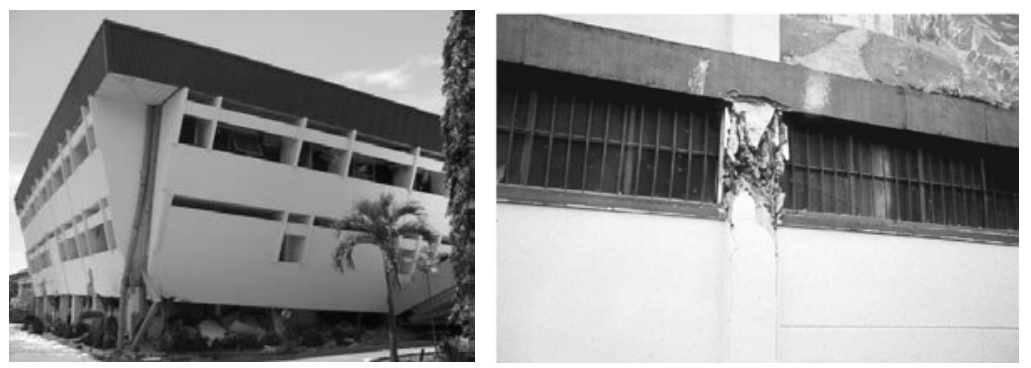

Figure 1 Negative effects of infill panels; soft storey mechanism [2] (left), short column mechanism [3](right)

Several experimental studies have been carried out aimed at investigating the behaviour of masonry-infilled frames, both in reinforced concrete $[4,5]$ and in steel $[6,7]$ structures. The added walls significantly increase the initial stiffness and lateral strength of the bare frame, but also change its dynamic properties. In [8], a decrease in the natural period of 50\% was found, resulting in a relevant change in the seismic demand of the structure. Another contribution of masonry infills is the provision of a higher energy dissipation capacity by increasing the damping ratio during earthquakes due to the cracking of the masonry walls [8]. A primary conclusion common to all previous studies is that the behaviour of the infilled frame is considerably influenced by the interaction between infill and surrounding frame. A further conclusion reached is that the lateral resistance of the infilled frame is not just equal to the sum of the lateral resistances of the infill and the surrounding frame, because the interaction between them alters their independent load resisting mechanisms [9].

A range of different studies have been conducted in order to identify the parameters potentially influencing the in-plane behaviour of infilled frames $[10,11]$. These parameters can be classified into three different categories: a) infill geometry and mechanical properties, with a state-of-the-art report regarding the in-plane properties and capacities of infilled frames presented in [12]; b) the geometry and mechanical properties of the surrounding frame; c) the characteristics of the infill-frame interface. For example, specimens with strong infills seem to exhibit better performance than those with weak infills in terms of lateral strength, initial stiffness and energy dissipation capacity [11].

Previous studies have also concentrated on the influence of openings and their position on the in-plane behaviour of infilled frames [6, 7, 11, 13-15]. A detailed review of research undertaken regarding masonry-infilled frames with openings was conducted by Surendran et al. [16]. Kakaletsis [11] and Asteris et al. [17] both concluded that the behaviour of the infilled frames, even in the presence of an opening, can significantly improve the performance of RC frames. The effect of different opening positions on the in-plane behaviour of infilled frames was examined by Mallick and Garg [14], who subsequently made recommendations as to the best position of the openings. Dawe et al. [7] applied the load laterally in one direction, concluding that moving the position of the opening towards the loading side decreases the ultimate load. In another study, Kakaletsis [13] also concluded that moving the opening towards the centre of the span results in a further decrease in lateral strength, stiffness and ductility. Asteris [18] and Giannakas et al. [19] proposed stiffness reduction factors of infilled frames in relation to opening percentages up to $49 \%$. In a study carried out by Mosalam et al. [6], four two-bay, one-storey specimens were tested, with the authors concluding that the presence of openings in the infills leads to a more ductile behaviour and reduces solid infill stiffness by about $40 \%$, for a lateral load below the cracking load level. Tasnimi et al. [15] tested six large-scale, singlestorey and single-bay infilled frames, with central openings of different dimensions. It was concluded that the presence of openings causes a reduction in the stiffness and lateral strength 
of the solid infilled frame. The test results indicated that infilled frames with openings are not always more ductile than those with solid infill.

Numerical analysis is usually employed as a complement to experimental work, contributing to a better understanding of infill and frame behaviour. As shown in Figure 2, infills can be modelled via the use of three different approaches: detailed micro models, simplified micro models and macro models [20]. The surrounding frame can be modelled using beam elements or continuum elements [21], while the interaction between infill and surrounding frame can be modelled based on interface elements [21]. In [22, 23], Asteris et al. undertook state-of-the-art mathematical micro and macro modelling of infilled frames, respectively. However, such analyses are complex and strut models are often used to represent the masonry infill in a simpler way.
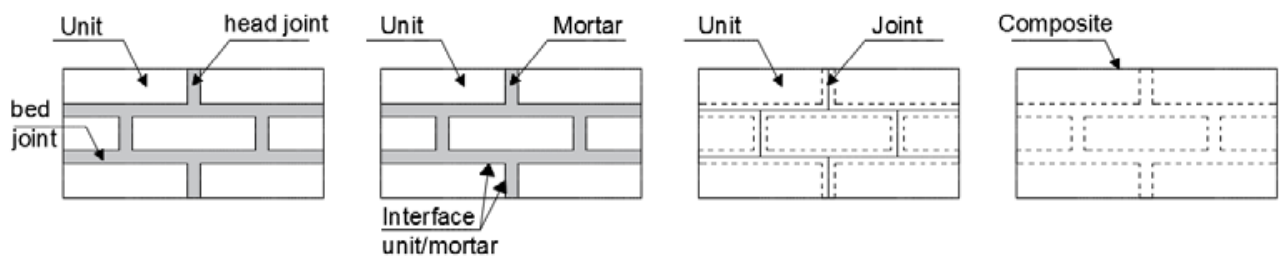

Figure 2 Different types of modelling for masonry structures: (a) part of a masonry wall; (b) detailed micro model; (c) simplified micro model; (d) macro model [20]

Three different types of strut model have been proposed to simulate the behaviour of infilled frames: single strut, double strut and triple strut [24, 25]. Experiments on masonry infill panels have also revealed that the equivalent strut must have a representative width in order to accurately represent the infill. Although a width of one-third of the diagonal length of the panel was initially proposed [26], alternative equations and charts were subsequently developed to calculate this width [27-38] (see [23, 39] for a review). In order to implement nonlinear dynamic or cyclic analysis, the force-displacement relationship of the diagonal strut must be taken into account by representing its hysteretic behaviour. A range of models has thus been proposed, taking into account the behaviour of the masonry infills in the equivalent diagonal strut [40-42]. Despite a number of researchers addressing the issue of openings in masonry infills, there are very few recommendations for practical use or which are normatively applicable. In the present paper, a new numerical model is first validated using recent experimental results. Subsequently, this model is employed for parametric analysis aimed at the development of formulas for lateral strength, stiffness and strut width, as a function of the size and location of openings.

\section{Brief Overview of the Experimental Campaign}

Calibration of the numerical model developed to analyse the in-plane cyclic behaviour of masonry infill walls was carried out based on the experimental results obtained by PauloPereira [4]. Three different masonry-infilled reinforced concrete frame specimens were tested under in-plane cyclic loading; details of the reinforced concrete frame are shown in Figure 3. The RC frames were designed according to EC8 [43] considering an average span often found in representative Portuguese RC buildings, with the masonry infills built using bricks with horizontal perforation and relatively low strength. Cyclic loading was applied in the plane of the panels in both positive and negative orientations by increasing the levels of the imposed horizontal displacement up to a pre-defined value of lateral drift. For each lateral drift, three cycles of loading and unloading were performed. This methodology of applying quasi-static load has been used by many researchers to simulate the response of structures to earthquake action [44]. Table 1 provides information regarding the materials and geometric configurations adopted for the masonry infill walls. Two single-leaf masonry infills were tested: one without rendering (Wall-Ref-01) and the other rendered with mortar (class M5) on both sides at $10 \mathrm{~mm}$ 
thickness (Wall-Ref-02). The third masonry wall (Wall-JAR) was reinforced at the bed joints every two courses with a prefabricated trussed reinforcement composed of two longitudinal bars connected by diagonal bars (Murfor RND 4/100 with 2\$4 longitudinal bars). The bricks, which are representative of the materials typically used for masonry infills in Portugal, were horizontally perforated. Test results for the specimens in terms of force-displacement diagrams are represented in Figure 4, and in terms of initial stiffness corresponding to 30\% of maximum lateral force, lateral strength and failure mode in Table 2, where the average of the test results in the two directions is shown. Displacement in this case corresponds to the displacement measured at the centre of the top beam-column node in the opposite corner to that where the horizontal actuator was connected. Rendering, applied here to the interior and exterior surfaces, increases the initial stiffness and load carrying capacity of the infilled frame, while the use of bed joint reinforcement mostly reduces cracking of the infilled frame.

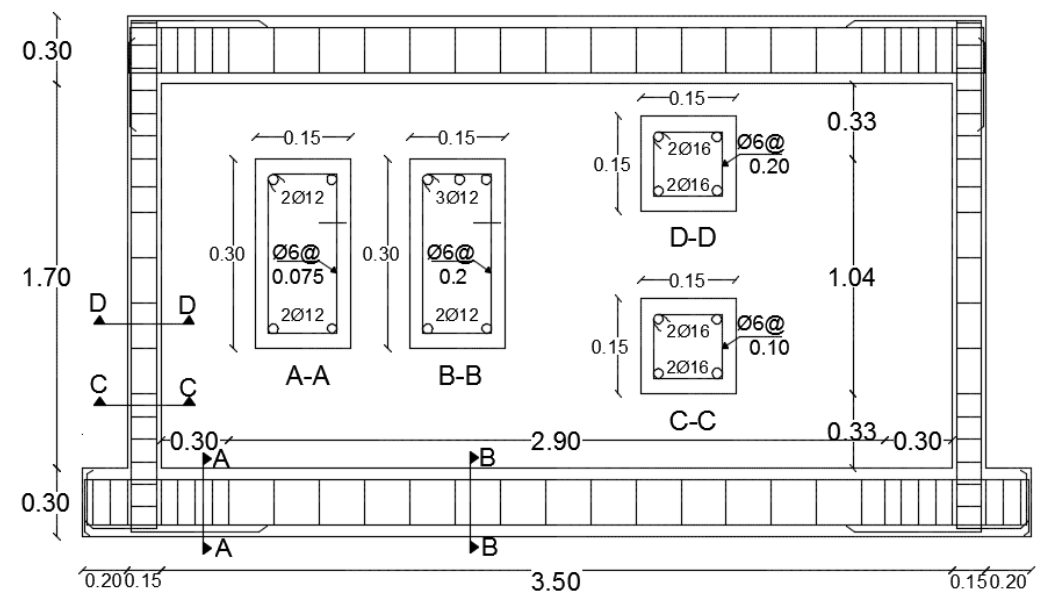

Figure 3 Geometry and reinforcement scheme of the tested specimens (dimensions in $\mathrm{m}$ ) [4]

Table 1 Information regarding the components of each brick masonry-infill masonry wall

\begin{tabular}{|c|c|c|c|}
\hline Specimen & Type of Panel & Components & Characteristics of materials \\
\hline Wall-Ref-01 & $\begin{array}{c}\text { Simple } \\
\text { (without rendering) }\end{array}$ & $\begin{array}{c}\text { Brick } \\
\text { Mortar }\end{array}$ & $\begin{array}{c}\text { With dimensions of } 0.30 \times 0.20 \times 0.15 \mathrm{~m} \\
\text { Mortar M5, } 10 \mathrm{~mm} \text { thickness }\end{array}$ \\
\hline Wall-Ref-02 & $\begin{array}{c}\text { Simple } \\
\text { (with rendering on } \\
\text { both sides) }\end{array}$ & $\begin{array}{c}\text { Brick } \\
\text { Mortar } \\
\text { Rendering } \\
\end{array}$ & $\begin{array}{l}\text { With dimensions of } 0.30 x 0.20 x 0.15 \mathrm{~m} \\
\text { Mortar M5, } 10 \mathrm{~mm} \text { thickness } \\
\text { Mortar M5, } 10 \mathrm{~cm} \text { thickness on each side }\end{array}$ \\
\hline Wall-JAR & Reinforced panel & $\begin{array}{c}\text { Brick } \\
\text { Mortar } \\
\text { Exterior rendering } \\
\text { Interior rendering } \\
\text { Reinforcement }\end{array}$ & $\begin{array}{c}\text { With dimensions of 0.30x0.20x0.15 m } \\
\text { Mortar M5, } 10 \mathrm{~mm} \text { thickness } \\
\text { Mortar M5, } 10 \mathrm{~mm} \text { thickness } \\
\text { Projected gypsum } \\
\text { BEKAERT- Murfor RND 4/100 with } 2 \$ 4 \text { longitudinal bars }\end{array}$ \\
\hline
\end{tabular}

Table 2 Initial stiffness and lateral strength of test specimens

\begin{tabular}{|c|c|c|c|}
\hline Test Specimen & $\begin{array}{c}\text { Average stiffness at 30\% } \\
\text { of maximum force }(\mathrm{N} / \mathrm{mm})\end{array}$ & $\begin{array}{c}\text { Average maximum } \\
\text { force }(\mathrm{N})\end{array}$ & Failure mode \\
\hline Wall-Ref-01 & 111800 & 85400 & Infill Crushing \\
\hline Wall-Ref-02 & 235600 & 181400 & Infill Crushing \\
\hline Wall-JAR & 128400 & 207100 & Infill Crushing \\
\hline
\end{tabular}

A brief scheme of the crack patterns developed in the test specimens is presented in Figure 5. It can be seen from this figure that the observed crack pattern is composed of cracks in the perimeter of the infill, likely due to the separation of the infill from its bounding frame and crushing of the infill in the vicinity of the horizontal load applied to the specimen. Crushing of 
the upper corners of the masonry infill walls occurs in all walls and can be considered the main feature of the failure mode (see Figure 6).

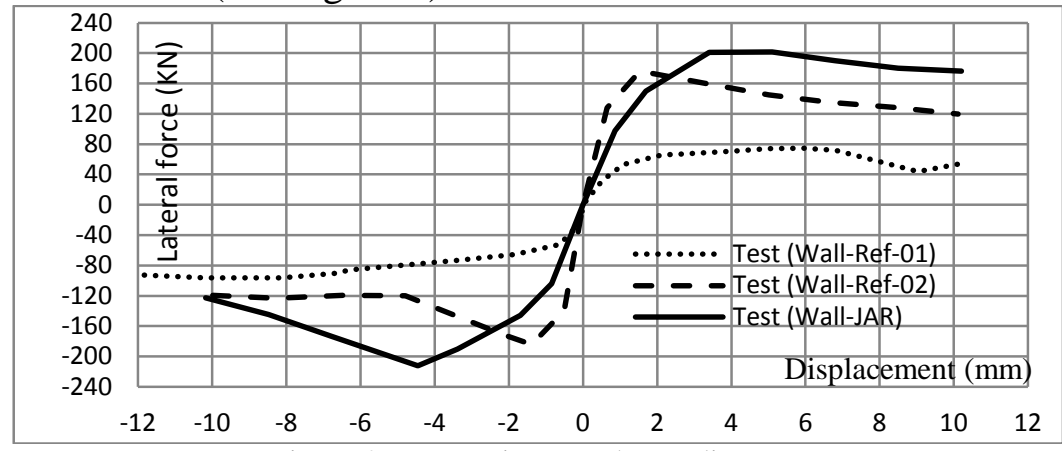

Figure 4 Test specimen pushover diagrams

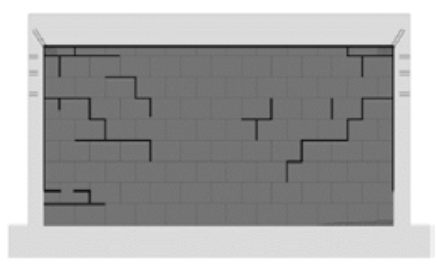

(a)

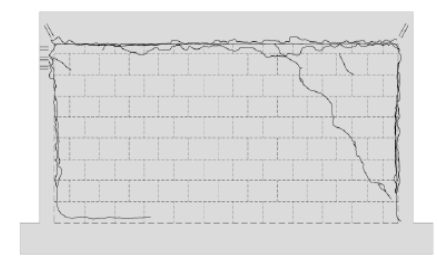

(b)

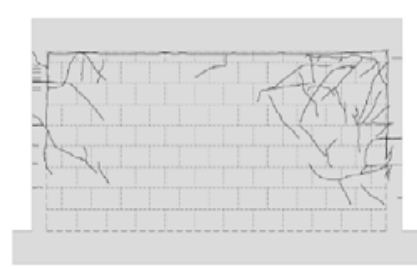

(c)

Figure 5 Crack patterns of test specimens a) Wall-Ref-01 b) Wall-Ref-02 c) Wall-JAR

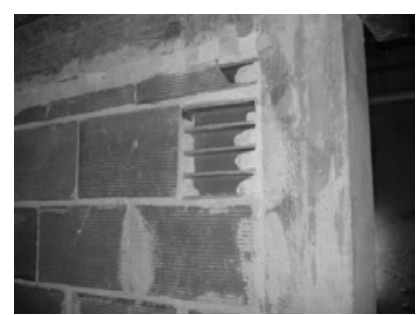

Figure 6 Crushing of loaded corner in a test specimen

\section{Validation of the Numerical Model}

\subsection{Finite element mesh and boundary conditions}

Numerical analysis of the in-plane behaviour of reinforced concrete frames with brick masonry infill walls was based on a finite element model built using the commercial software program DIANA [45]. For this purpose, a bi-dimensional model of the reinforced concrete frame with brick masonry infill tested during the experimental campaign was adopted, with the masonry infill and its surrounding frame represented by four-noded plane-stress elements. Reinforcement was also added to the concrete frame in the form of embedded bars, perfectly bonded. The connection between the masonry infill walls and the reinforced concrete frames was simulated through four-noded interface elements. The lower beam of the frame was fixed by preventing any translation in the $\mathrm{x}$ and $\mathrm{y}$ directions in the numerical analysis. This boundary condition is the same as that adopted during the testing campaign. A vertical load of $50 \mathrm{kN}$ was placed at the top of each column, because it is expected that the vertical load is not transmitted by the top beam to the masonry infill as it is considered a non-structural element. If the top slab or beam were to deform due to creep or additional loading, some vertical loading would be transferred to the masonry infill; however, this scenario is beyond the scope of the present research. The intention of this paper was to validate the numerical model using the test results of Wall-Ref-01, with the validated model then employed to predict test results for Wall-Ref02 and Wall-JAR.

\subsection{Material models and mechanical properties}

The non-linear behaviour of the concrete and masonry was represented by a Total Strain Crack Model based on the fixed stress-strain law concept available in DIANA [45]. The model 
describes the tensile and compressive behaviour of the material via one stress-strain relationship in the local coordinate system that is fixed upon crack initiation. Exponential and parabolic constitutive laws were used to describe the tensile and compressive behaviour of concrete and masonry infill, respectively, as shown in Figure 7.

a)

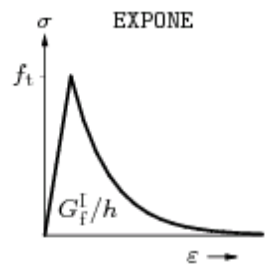

b)

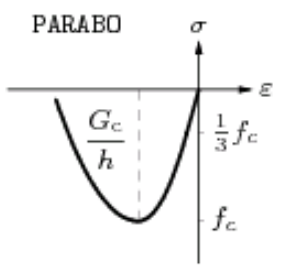

Figure 7 Stress-strain relationship adopted for the Total Strain Crack model: a) exponential softening curve describing tension and b) parabolic constitutive laws describing compression

An interface cap model, plasticity based and proposed by Lourenço and Rots [46] was used for the interface elements describing the connection between the brick masonry infill wall and the enclosure RC frame. This interface material model is widely considered appropriate to simulate fracture, frictional slip, as well as crushing along the interface [46]. As shown in Figure 8, fracture of the interface is controlled by its tension mode, shear behaviour by Coulomb friction behaviour and crushing by the cap in compression mode.

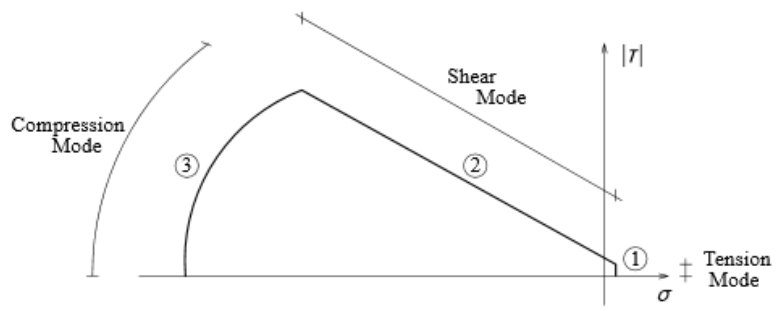

Figure 8 Two-dimensional interface yield function [47]

One drawback regarding the use of this interface model is the lack of material properties, as no data were available regarding the behaviour of the interface between the masonry infill and the frame. Therefore, it was decided to define the material properties of the interface by fitting the numerical results to the experimental results obtained for Wall-Ref-01, both at the level of the monotonic envelope of the hysteresis loops and at the level of the failure mode; validation was then provided by the other wall tests. A summary of the mechanical properties adopted for the interfaces is presented in Table 3, including the elastic properties (normal stiffness $K_{n}$ and shear stiffness $K_{s}$ ) and material parameters describing the tensile fracture behaviour (tensile strength, $f_{t}$, and mode I fracture energy, $G_{f}^{I}$ ), the shear fracture process (cohesion, $c$, friction angle, $\phi$, dilatancy angle, $\psi$, and mode II fracture energy, $G_{f}^{I I}$ ) and the compression behaviour (compressive strength, $f_{c}$, and compressive fracture energy, $\mathrm{G}_{c}$ )

Table 3 Mechanical properties adopted for the interface elements

\begin{tabular}{|c|c|c|c|c|c|}
\hline \multirow[t]{2}{*}{ Elastic Properties } & & \multicolumn{2}{|c|}{$K_{n}\left(\mathrm{~N} / \mathrm{mm}^{3}\right)$} & \multicolumn{2}{|c|}{$K_{s}\left(\mathrm{~N} / \mathrm{mm}^{3}\right)$} \\
\hline & & \multicolumn{2}{|c|}{9.3} & \multicolumn{2}{|c|}{5.4} \\
\hline \multirow{6}{*}{ Nonlinear Properties } & \multirow{2}{*}{ Tension } & \multicolumn{2}{|c|}{$f_{t}\left(\mathrm{~N} / \mathrm{mm}^{2}\right)$} & \multicolumn{2}{|c|}{$G_{f}^{I}(\mathrm{~N} / \mathrm{mm})$} \\
\hline & & \multicolumn{2}{|c|}{0.05} & \multicolumn{2}{|c|}{0.05} \\
\hline & \multirow{2}{*}{ Shear } & c $\left(\mathrm{N} / \mathrm{mm}^{2}\right)$ & $\phi$ & $\psi$ & $G_{f}^{I I}(\mathrm{~N} / \mathrm{mm})$ \\
\hline & & 0.07 & 0.5 & 0.0001 & 0.3 \\
\hline & \multirow{2}{*}{ Compression } & \multicolumn{2}{|c|}{$f_{c}\left(\mathrm{~N} / \mathrm{mm}^{2}\right)$} & \multicolumn{2}{|c|}{$G_{c}(\mathrm{~N} / \mathrm{mm})$} \\
\hline & & \multicolumn{2}{|c|}{30} & \multicolumn{2}{|c|}{8} \\
\hline
\end{tabular}

The mechanical properties used for the masonry (Wall_Ref_01) and concrete, which are displayed in Table 4, were obtained based on a set of experimental tests carried out by PauloPereira [4] (compressive and flexural tests on brick masonry wallets). For Wall-Ref-02 and 
Wall-JAR, it was necessary to update the mechanical properties of the interface elements to take into account the rendering on both sides of the walls, as well as the reinforcement at the bed joints. It is evident that the presence of rendering and bed joint reinforcement will change the mechanical properties of the interface elements representing the connection between infill and surrounding frame.

Table 4 Mechanical properties of the components for walls specimens [4]

\begin{tabular}{|l|c|c|c|c|}
\hline \multirow{2}{*}{ Mechanical Properties } & Concrete & Wall-Ref-01 & Wall-Ref-02 & Wall-JAR \\
\hline Young's Modulus (GPa) & 31.5 & 1.67 & 3.83 & 4.43 \\
\hline Poisson's ratio & 0.15 & 0.13 & 0.237 & 0.175 \\
\hline Tensile Strength (MPa) & 2.35 & 0.25 & 0.4 & 0.5 \\
\hline Mode-I fracture Energy (N/mm) & 0.10 & 0.02 & 0.03 & 0.03 \\
\hline Compressive Strength (MPa) & 31.5 & 1.00 & 1.26 & 1.97 \\
\hline Compressive Fracture Energy (N/mm) & 8.0 & 1.0 & 1.0 & 1.0 \\
\hline Yield Stress of Concrete Reinforcements(MPa) & - & 500 & 500 & 500 \\
\hline
\end{tabular}

The mechanical properties of the interface elements of Wall-Ref-02 and Wall-JAR were calculated by modifying the mechanical properties of the interface considered in Wall-Ref-01. The updating of the mechanical properties of the masonry infill with rendering on both sides was carried out by considering the geometric association between the masonry infill with thickness $t_{w}$ and the new mortar layers with thickness $t_{r}$, as shown in Figure 9. Thus, the equivalent value of the interface's tensile strength in specimen Wall_Ref_02 is obtained through equation (1) as follows:

$$
f_{\text {tin }}=\frac{\left(f_{t i} \times t_{w}\right)+\left(f_{t r} \times t_{r}\right)}{t_{\text {all }}}
$$

where $f_{t i n}$ is the equivalent tensile bond strength of the interface in new condition (with rendering), $f_{t i}$ is the tensile bond strength of the interface without rendering, $f_{t r}$ is the tensile bond strength of the rendering material, $t_{w}$ is the thickness of the infill wall without rendering $(15 \mathrm{~cm}), t_{r}$ is the thickness of the mortar rendering layers $(1 \mathrm{~cm})$ and $t_{\text {all }}$ is the entire thickness of the wall after rendering. The mechanical properties of the interface after adding the rendering, such as elastic properties (shear and normal stiffness), cohesion and Mode II fracture energy, were also calculated according to the same averaging procedure. A summary of the mechanical properties of the interfaces (updated after rendering) of specimens Wall-Ref-02 and Wall-JAR is presented in Table 5. Friction and dilatancy angles were here considered roughly equal for the rendering walls.

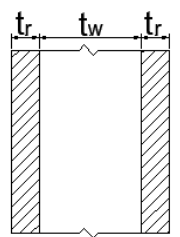

Figure 9 Thickness of the brick-infill masonry walls after rendering in contact with the concrete enclosure

Table 5 Mechanical Properties of the interface after rendering

\begin{tabular}{|l|c|c|}
\hline \multicolumn{1}{|c|}{ Interface Mechanical Properties } & Wall-Ref-02 & Wall-JAR \\
\hline Normal stiffness, $K_{n}\left(\mathrm{~N} / \mathrm{mm}^{3}\right)$ & 24.18 & 33.48 \\
\hline Shear Stiffness, $K_{s}\left(\mathrm{~N} / \mathrm{mm}^{3}\right)$ & 14.04 & 19.44 \\
\hline Tensile strength, $f_{t}\left(\mathrm{~N} / \mathrm{mm}^{2}\right)$ & 0.13 & 0.18 \\
\hline Mode I fracture energy, $G_{f}^{I}(\mathrm{~N} / \mathrm{mm})$ & 0.13 & 0.18 \\
\hline Cohesion, $c\left(\mathrm{~N} / \mathrm{mm}^{2}\right)$ & 0.2 & 0.263 \\
\hline Mode II fracture energy, $G_{f}^{I I}(\mathrm{~N} / \mathrm{mm})$ & 0.9 & 1.1 \\
\hline
\end{tabular}




\subsection{Analysis of numerical results}

A comparison of the force-displacement diagrams obtained during the experimental and numerical analysis of Wall-Ref-01 can be seen in Figure 10. From this figure it is apparent that there is a good agreement between the numeric monotonic curve and the monotonic experimental envelopes for both the positive and negative directions (for convenience the result of "test-" is shown in the positive direction), in terms of both lateral resistance and ultimate deformation. There is also a good agreement in terms of the pre-peak regime, where the linear stiffness and the pre-peak nonlinear regime are well described by the numerical model.

According to the conducted numerical analysis, when in-plane lateral load is applied to the structure the infilled frame acts as a monolithic resisting system at low lateral load level. As the load increases, the infill tends to partially separate from the enclosure frame and stress concentration develops along a strut. This behaviour is schematically shown in Figure 11a. The upper left and bottom right corners of infill detach from the RC frame at lateral loads of 55KN and $65 \mathrm{kN}$, respectively, in agreement with the test results.

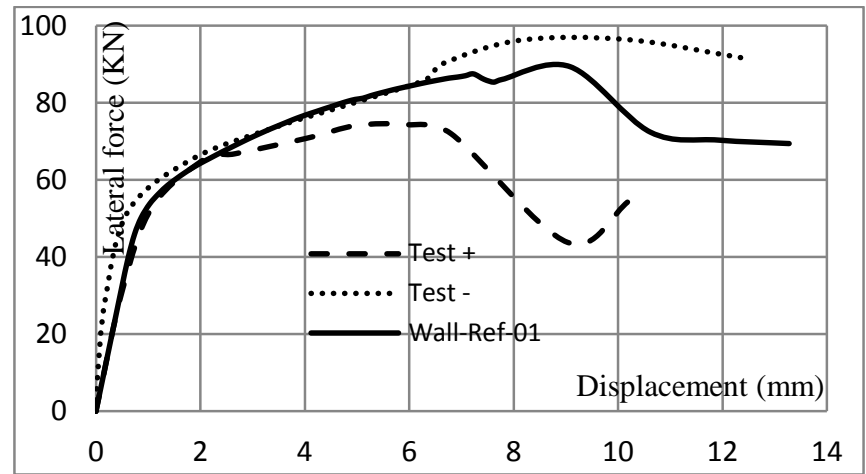

Figure 10 Pushover diagrams of the numerical model versus experimental results (Wall-Ref-01)

It should also be noted that the failure mode of the numerical model is compatible with that recorded in the test results. As shown in Figure 11b, the deformed mesh observed in the numerical model of the infill panel at failure demonstrates the crushing of the infill at the extremities of the diagonal compression strut. This result matches the failure mode of the test results shown in Figure 6.

a)

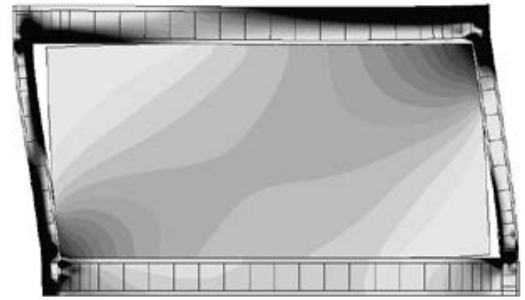

b)

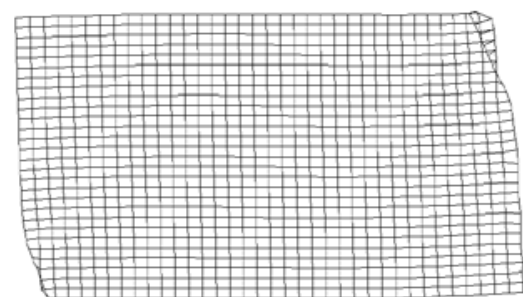

Figure 11 a) Schematic distribution of minimum principal stresses in the numerical model (Wall-Ref-01); b) Deformed mesh of the infill panel at failure

The static nonlinear analysis performed on walls Wall-Ref-02 and Wall-JAR in order to evaluate their in-plane cyclic behaviour is summarised in Figure 12, in which the numerical nonlinear monotonic and experimental monotonic envelopes of the force-displacement diagrams are compared. For convenience, the results obtained in both directions are represented in the positive direction only. It can be seen from this figure that the developed numerical model is able to predict the results of the experimental tests very satisfactorily, with the numerical results again confirming that the rendering of the infilled masonry walls results in a considerable increase in in-plane lateral resistance. 
The results obtained regarding initial stiffness, calculated as the slope of the force-displacement diagram at $30 \%$ of the maximum lateral resistance, and lateral strength are displayed in Table 6. Rendering increases the lateral strength of the wall by about $100 \%$, while the placement of bed joint reinforcement along with the rendering of both sides increases this value to about $130 \%$. Both numerical models produce the same failure pattern as infill crushing, a finding again compatible with the experimental results.

a)

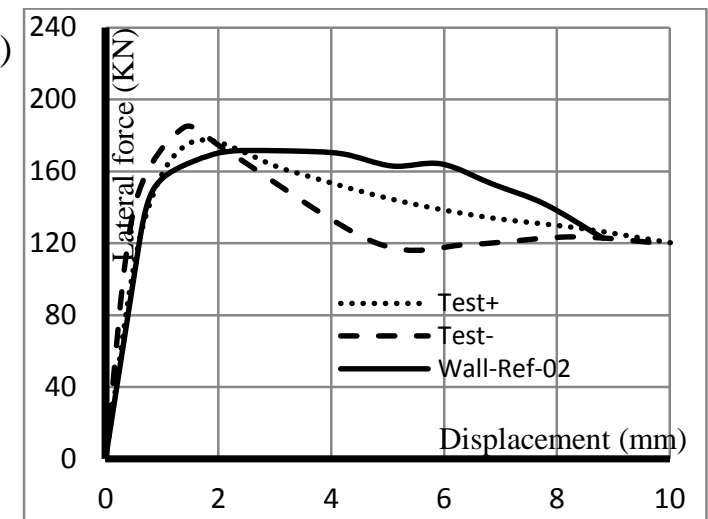

b)

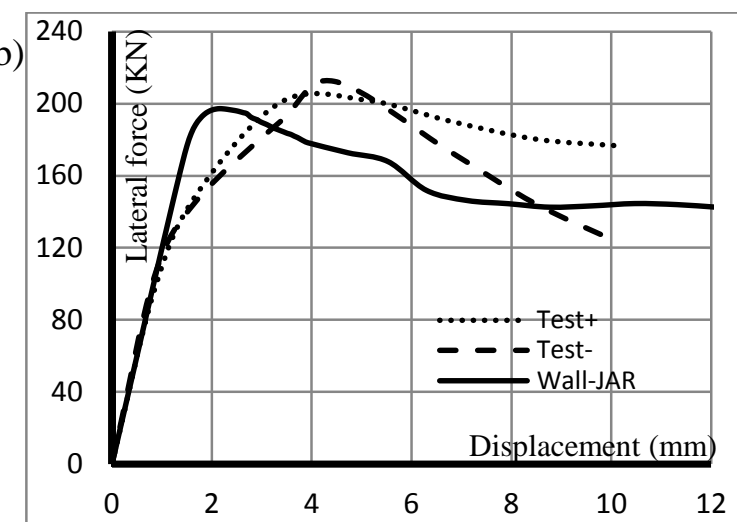

Figure 12 Comparison between the force-displacement diagrams obtained in the experimental program and the results of numerical analysis: a) Wall-Ref-02; b) Wall-JAR

Table 6 Results of numerical analysis in terms of initial stiffness, lateral strength and failure mode

\begin{tabular}{|c|c|c|c|}
\hline Numerical Model & Initial stiffness at $\mathbf{3 0 \%}$ of $P_{\max }(\mathrm{N} / \mathrm{mm})$ & Lateral Strength (N) & Failure Mode \\
\hline Wall-Ref-02 & 201000 & 171500 & Infill Crushing \\
\hline Wall-JAR & 120000 & 197500 & Infill Crushing \\
\hline
\end{tabular}

It should be stressed that the numerical model is also able to characterise the effect of the addition of horizontal reinforcement at the bed joints on the lateral resistance. An increase of $12 \%$ in lateral resistance was recorded in the case of specimen Wall-JAR in relation to WallRef-02. It can therefore be concluded that the proposed numerical model adequately replicates the experimental tests.

\section{Parametric Analysis}

The parametric analysis aimed to evaluate the mechanical behaviour of masonry infill walls with distinct types of openings under static loading. In more detail, the work presented in this section can be divided into three parts: (1) assessment of the influence of the percentage of central window openings on lateral stiffness and resistance; (2) evaluation of opening type and location on lateral stiffness and resistance, also including the development of a formula taking into account the width and height of piers in infills with typical openings; (3) assessment of the influence of the openings on the width of the compression strut that represents the masonry infill.

\subsection{Influence of central opening}

In the first phase, the influence of a central opening and variation in its area on the in-plane behaviour of the masonry-infilled RC frame was investigated by considering different openings in the numerical model. Variation in the area of the central opening was here defined by multiplying the original dimensions of the infill by a factor "a” (see Figure 13 and Table 7), with the model name defined as $\mathrm{O}(\mathrm{x} \%)$, where $\mathrm{x}$ is the ratio of opening area to total infill area. The boundary conditions were the same as those considered in the calibrated model. Static nonlinear analysis was performed by applying increasing lateral load at the upper beam. 


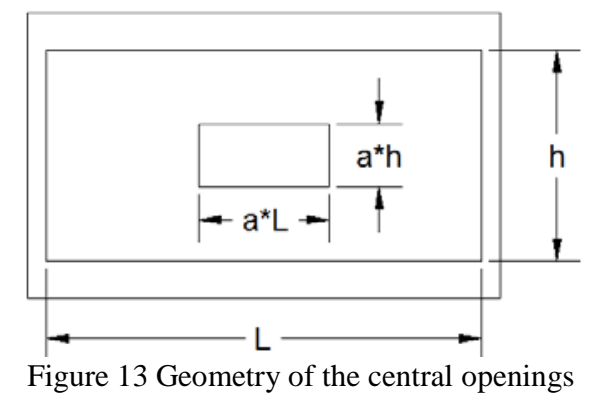

Table 7 Geometric characterisation of the openings

\begin{tabular}{|l|c|c|c|c|c|c|}
\hline Model Name & a (constant) & $\begin{array}{c}\text { Length of } \\
\text { Opening }\end{array}$ & $\begin{array}{c}\text { Height of } \\
\text { Opening }\end{array}$ & $\begin{array}{c}\text { Length of } \\
\text { Infill }\end{array}$ & $\begin{array}{c}\text { Height of } \\
\text { Infill }\end{array}$ & $\begin{array}{c}\text { Percentage } \\
\text { ratio of } \\
\text { Opening Area } \\
\text { to Infill Area }\end{array}$ \\
\hline Without opening & 0 & 0 & 0 & 3500 & 1700 & $0 \%$ \\
\hline $\mathbf{O ( 9 \% )}$ & 0.3 & 1050 & 510 & 3500 & 1700 & $9 \%$ \\
\hline $\mathbf{O ( 1 2 \% )}$ & 0.35 & 1225 & 595 & 3500 & 1700 & $12 \%$ \\
\hline $\mathbf{O ( 1 5 \% )}$ & 0.39 & 1365 & 663 & 3500 & 1700 & $15 \%$ \\
\hline $\mathbf{O ( 2 0 \% )}$ & 0.45 & 1575 & 765 & 3500 & 1700 & $20 \%$ \\
\hline $\mathbf{O ( 2 5 \% )}$ & 0.5 & 1750 & 850 & 3500 & 1700 & $25 \%$ \\
\hline $\mathbf{O ( 3 0 \% )}$ & 0.55 & 1925 & 935 & 3500 & 1700 & $30 \%$ \\
\hline $\mathbf{O ( 3 6 \% )}$ & 0.6 & 2100 & 1020 & 3500 & 1700 & $36 \%$ \\
\hline $\mathbf{O ( 3 9 \% )}$ & 0.625 & 2190 & 1060 & 3500 & 1700 & $39 \%$ \\
\hline $\mathbf{O ( 4 2 \% )}$ & 0.65 & 2275 & 1105 & 3500 & 1700 & $42 \%$ \\
\hline $\mathbf{O ( 4 5 \% )}$ & 0.675 & 2360 & 1145 & 3500 & 1700 & $46 \%$ \\
\hline $\mathbf{O}(49 \%)$ & 0.7 & 2450 & 1190 & 3500 & 1700 & $49 \%$ \\
\hline Bare Frame & 1 & 3500 & 1700 & 0 & 0 & $100 \%$ \\
\hline
\end{tabular}

Crack propagation in the specimen with a 30\% central opening area is presented in Figure 14, with the lateral load applied from right to left. During the early stages of loading, cracks appear at the upper right and bottom left corners of the opening as a result of the stress concentration along the compression strut. By increasing the lateral load, the cracking path extends to the other corners of the opening and also appears in the bounding RC elements. This occurs in all numerical models with any opening percentage. As the lateral load increases, the cracking density increases considerably, resulting in the failure of the composite structure.

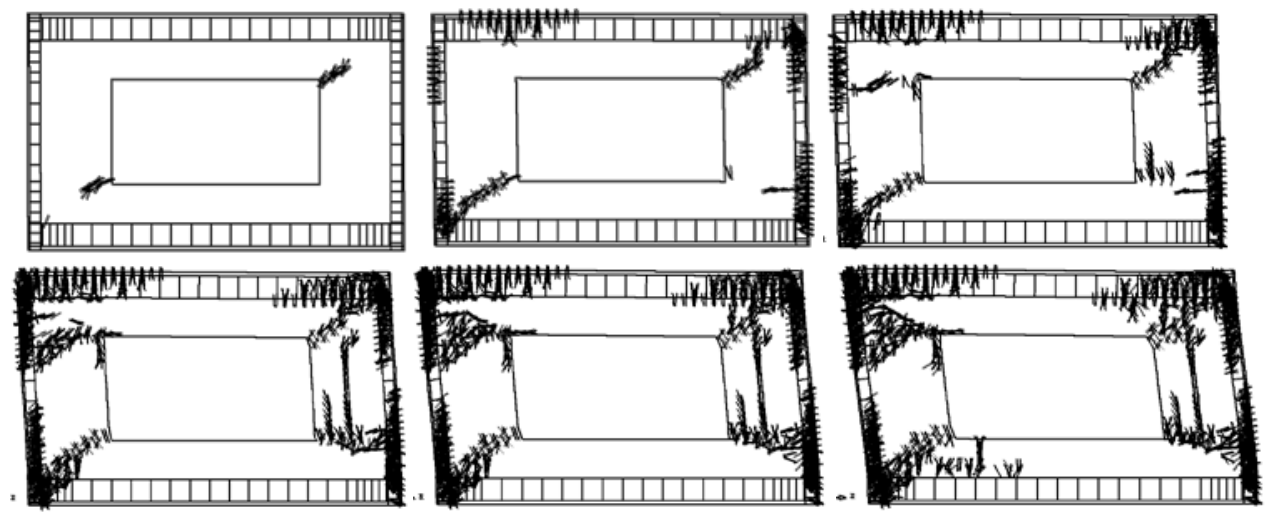

Figure 14 Schematic representation of crack propagation in the numerical models caused by increasing lateral load

The distribution of minimum principal stresses (compressive stresses) over the infilled frame shows that for low levels of loading, two diagonal struts form within the infill, passing through the upper left and lower right corners of the openings (Figure 15). This means that for low levels of loading, crack formation in the lower left and upper right corners is due to tensile stresses; then, by increasing the lateral load, further cracks form in the areas that the struts 
formed around the lower right and upper left corners of the opening, due to compressive stresses.

Pushover force-displacement diagrams of the numerical models, displayed in Figure 16, were constructed in order to better understand the influence of opening area on in-plane behaviour. All numerical analyses were continued until a lateral drift of $2 \%$ had been reached in order to obtain the relevant parameters such as initial stiffness, lateral strength and the displacement corresponding to the lateral strength. By analysing the force-displacement diagrams, it is clear that the central opening percentage influences the lateral behaviour of the infilled frames, particularly lateral stiffness (calculated as the tangent stiffness at 30\% of the lateral resistance), lateral strength and displacement at which the lateral strength is achieved. It can be observed in Figure 16 that the displacement corresponding to the peak lateral load increases as the opening area increases. This is related to the reduction of the contribution of the masonry infill to the lateral strength as the area of the central opening of the masonry infill increases. At the limit, when the percentage of the central opening is very high, the behaviour of the infilled frame approaches that of the bare frame. In any case, the ultimate resistance corresponding to the lateral drift of $2 \%$ converges to a constant value, which is associated to the resistance of the bare frame.

It is also apparent that by increasing the area of the central opening, lateral strength and stiffness decrease. Furthermore, for small opening areas the decrease in lateral stiffness is higher than that of lateral strength, as illustrated in Figure 17.

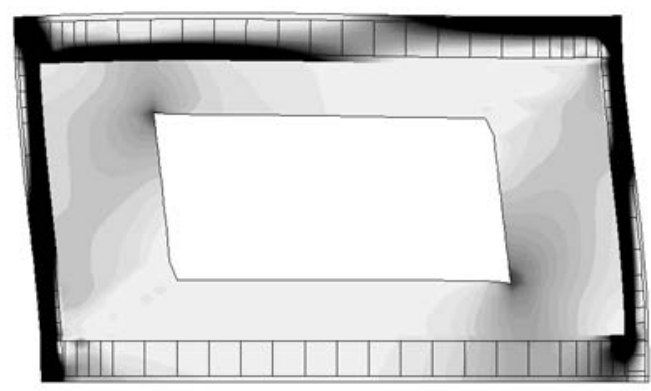

Figure 15 Schematic distribution of minimum principal stresses

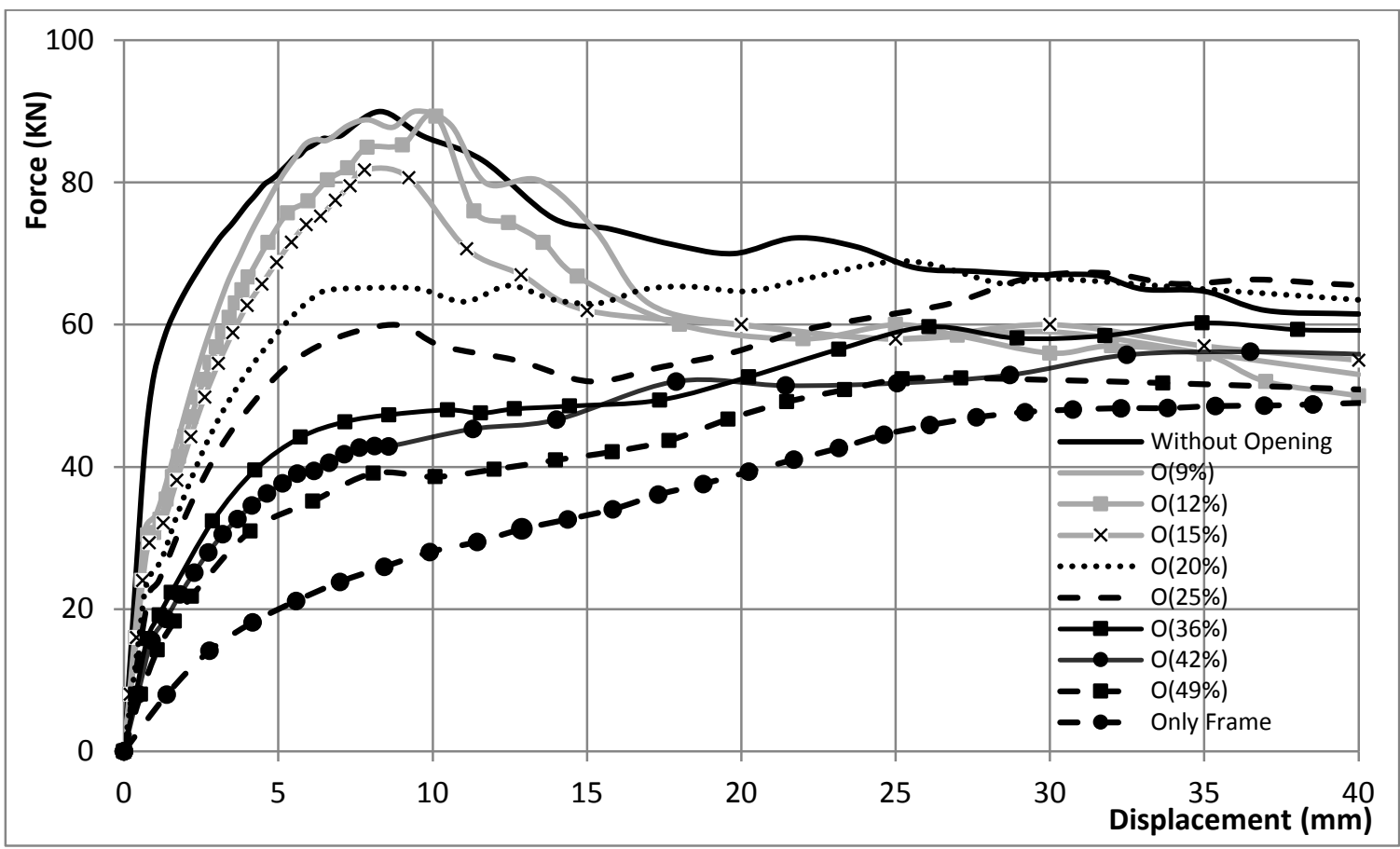

Figure 16 Pushover diagrams of the numerical models with increasing opening ratio 


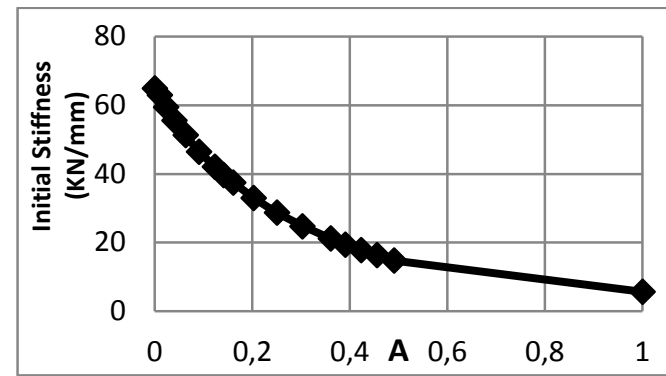

a)

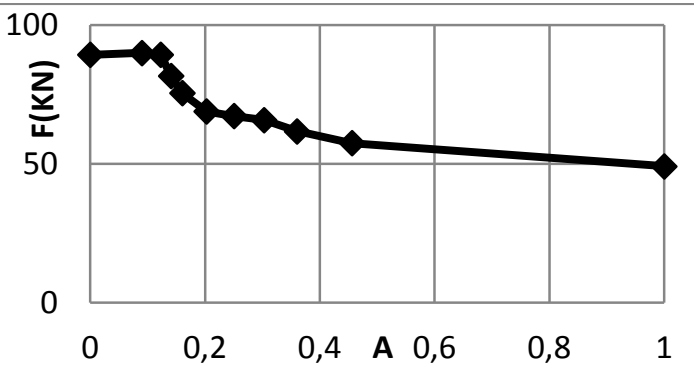

b)

Figure 17 Influence of opening area A on the mechanical properties of the RC masonry infill: a) variation in initial stiffness; b) variation in lateral strength

The trend of variation in the initial stiffness of the infilled frames recorded in the present study is compared with those obtained by Asteris [18] and Giannakas et al. [19] in Figure 18. It can be observed from this figure that the results obtained here are similar to those of [19] until a ratio of $49 \%$ opening area to infill area is reached.

Aiming to mathematically define the variation in the lateral resistance and stiffness with opening area, a simplified approach was considered in order to predict the initial stiffness of the masonry-infilled RC frame with central opening; see equation (2):

$$
K_{c o}=\left[\left(K_{\text {fill }}-K_{\text {bare }}\right) \times(1-A)^{n}\right]+K_{\text {bare }}
$$

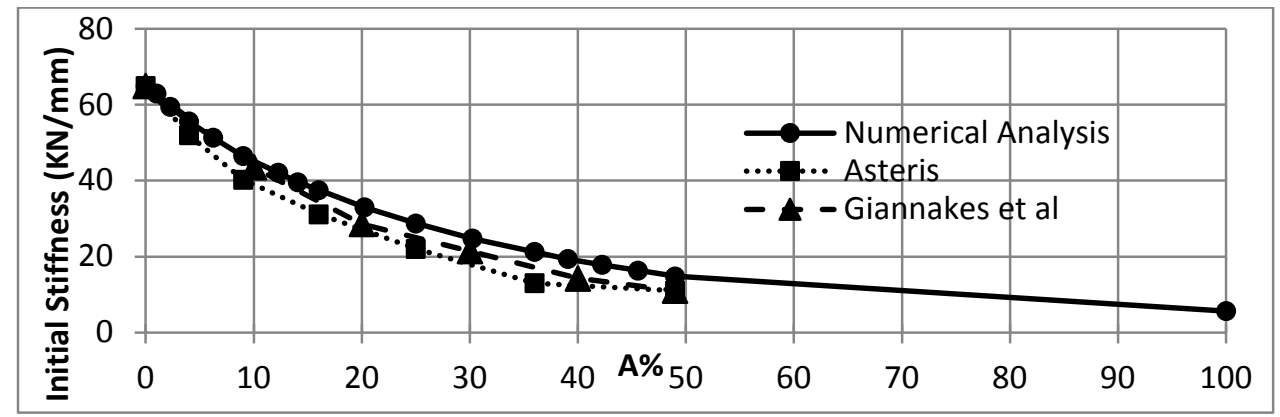

Figure 18 Trend of variation in initial stiffness with increasing opening area \% for different researchers

where $K_{c o}$ is the initial stiffness of the infilled frame with central opening, $K_{\text {fill }}$ is the initial stiffness of the solid infilled frame, $K_{\text {bare }}$ is the initial stiffness of the frame and $A$ is the opening area to infill area ratio. A best fit provides a value for " $n$ " equal to 3 , with a coefficient of determination $r^{2}$ of 0.988 , see Figure 19a. Thus, equation (2) can be rewritten as:

$$
K_{c o}=\left[\left(K_{\text {fill }}-K_{\text {bare }}\right) \times(1-A)^{3}\right]+K_{\text {bare }}
$$

A simplified approach was also used to determine mathematical equations for the lateral strength of the masonry-infilled RC frames for any area of central opening, as shown in Figure 19b. In this approach, the lateral strength is expressed as:

$$
F_{c o}=\left[\left(F_{\text {fill }}-F_{\text {bare }}\right) \times(1.1396 \times(1-A))^{n}\right]+F_{\text {bare }}
$$

where $F_{c o}$ is the lateral strength of the RC infilled frame with central opening, $F_{\text {fil }}$ is the lateral strength of the solid infilled frame and $F_{\text {bare }}$ is the lateral strength of the reinforced concrete frame. The best fit is obtained for a value of $n$ equal to 4.3 with $r^{2}$ equal to 0.975 , with equation (4) thus rewritten on this basis as: 


$$
F_{c o}=\left[\left(F_{\text {fill }}-F_{\text {bare }}\right) \times(1.1396 \times(1-A))^{4.3}\right]+F_{\text {bare }}
$$

a)

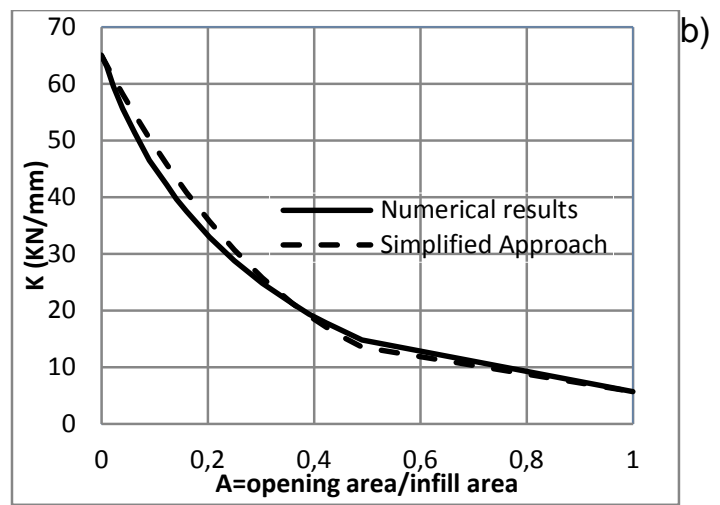

b)

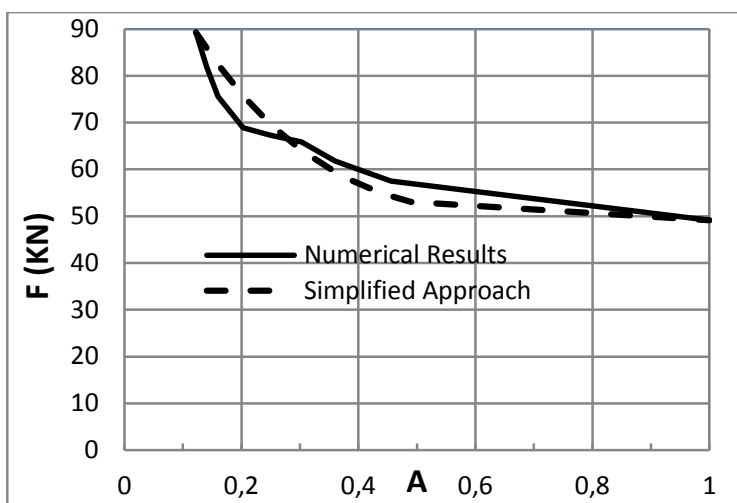

Figure 19 Simplified and detailed approaches for: a) initial stiffness; b) lateral strength

Although calibration of the numerical model was here based on the solid infill, the global results of the numerical model with opening are satisfactorily compatible with those obtained by other researchers $[11,13]$. For instance, movement of the opening towards the centre of the span results in a further decrease in lateral strength and stiffness, as also found in [13].

\subsection{Influence of typical openings}

Although a central opening is representative of a number of geometric configurations of masonry infill walls, other types of opening are also found within masonry infills, typically associated with double windows and combinations of windows and doors. The most common openings used in southern European countries have been categorised in [48] and are here shown in Figure 20. As the position of openings is known to affect the lateral behaviour of masonryinfilled RC frames [11, 18], a detailed study was carried out regarding the influence of the distinct types of opening typically observed in masonry infill walls in southern European countries.

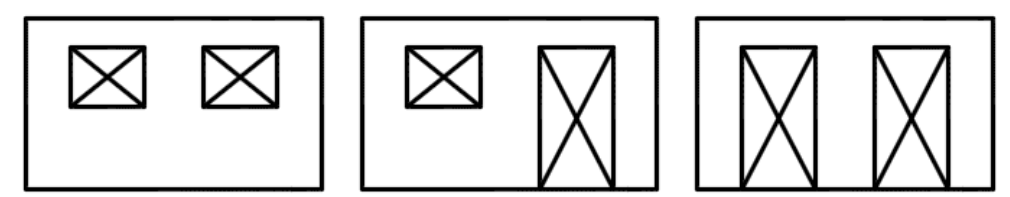

Figure 20 Typical openings in masonry infill walls in southern European Countries

The distribution of the minimum principal stresses corresponding to the first steps of loading in the $-\mathrm{x}$ direction for the studied three opening typologies is presented in Figure 21. From this figure it is apparent that three diagonal struts develop both in the central pier between the openings and in the lateral piers between the openings and the RC frame. The inclination of these struts and the developing stresses depends on the height to length ratio of the piers. This stress distribution indicates that the diagonal struts provide the stiffness of the infilled frame and also withstand the lateral load that is applied to the structure, meaning that the cross section or the width of the piers in which the diagonal struts develop is of the utmost importance. By comparing the diagonal struts within the infills of walls $\mathrm{O}(2 \mathrm{~W}) 1, \mathrm{O}(2 \mathrm{D}) 1$ and $\mathrm{O}(\mathrm{DW}) 1$ (see Figure 21 for wall labels), it can be concluded that the stiffness and lateral strength of wall $\mathrm{O}(2 \mathrm{~W}) 1$ are considerably larger than those of $\mathrm{O}(2 \mathrm{D}) 1$ and $\mathrm{O}(\mathrm{DW}) 1$, likely due to the greater width of the three struts formed in wall $\mathrm{O}(2 \mathrm{~W}) 1$. This finding forms the basis of the analytical work aimed at predicting the lateral stiffness and strength of masonry infills with openings, which is discussed later in this section. The initial cracks develop in the corners due to the tensile stresses; an increase in the lateral load subsequently results in the appearance of further cracks in the corners where the compressive struts were formed, due to the large compressive 
stresses (see Figure 22). This crack propagation pattern occurs similarly in the models with typical openings. Taking into account the three studied opening typologies of masonry infill walls, it was decided to study the influence of different opening positions on the in-plane behaviour, as shown in Figure 23 to Figure 25.
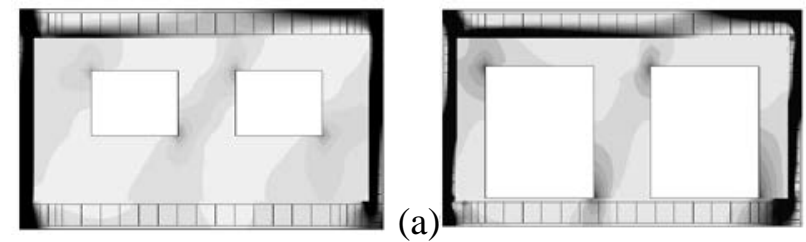

(b)

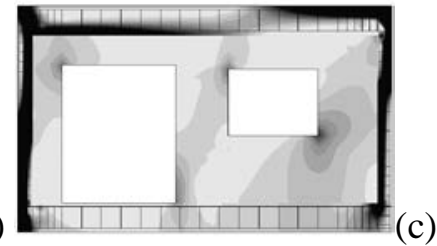

Figure 21 Schematic distribution of minimum principle stresses in: (a) wall $\mathrm{O}(2 \mathrm{~W}) 1$; (b) wall $\mathrm{O}(2 \mathrm{D}) 1$; (c) wall $\mathrm{O}(\mathrm{DW}) 1$

All walls were numerically simulated in DIANA using the material properties employed in the calibrated Wall-Ref-01 model and analysed via static nonlinear analysis. The results of this analysis in terms of initial stiffness and lateral strength are displayed in Table 8. For the cases in which the openings are not symmetrical within each typology, the minimum values of initial stiffness and lateral strength are adopted due to the cyclic nature of earthquakes. For instance, for walls $\mathrm{O}(2 \mathrm{~W}) 2$ and $\mathrm{O}(2 \mathrm{~W}) 3$, the wall with the lower values of initial stiffness and lateral strength, namely $\mathrm{O}(2 \mathrm{~W}) 3$, was selected for investigation in Table 8.
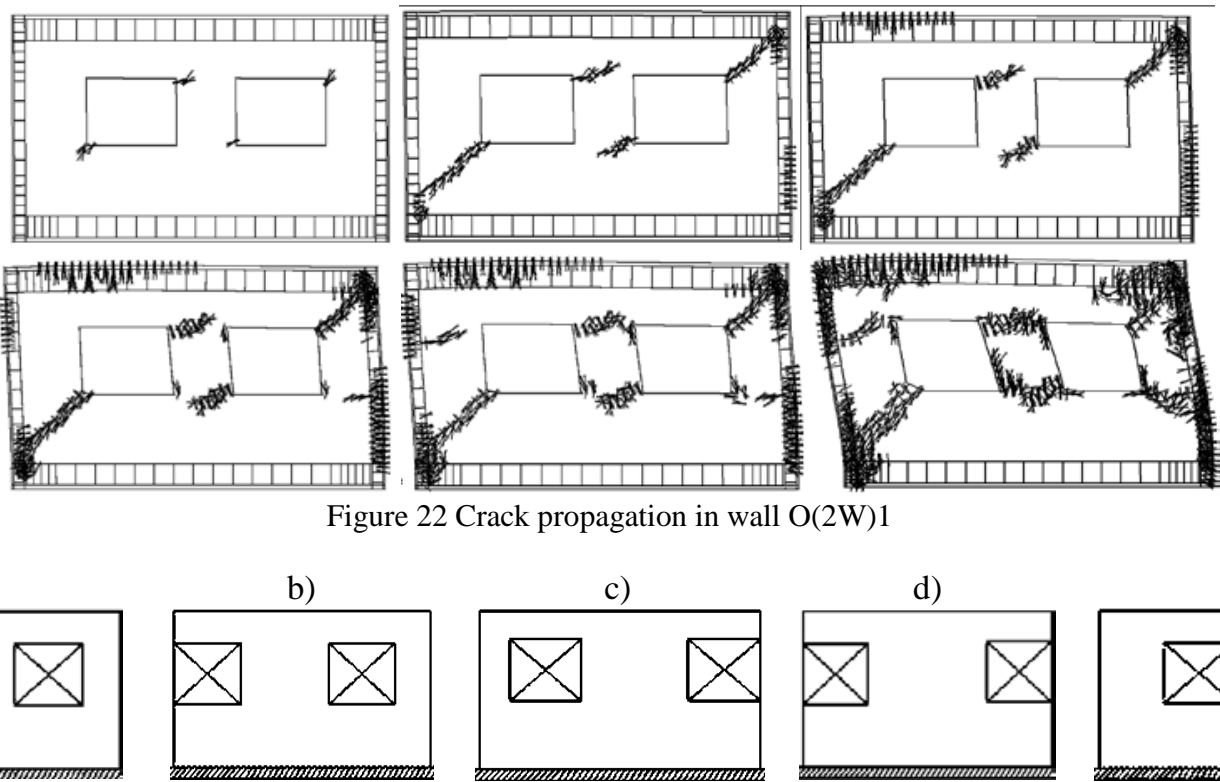

Figure 22 Crack propagation in wall $\mathrm{O}(2 \mathrm{~W}) 1$

a)

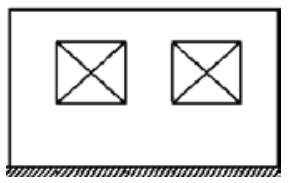

Figure 23 Possible positions of window oper b)

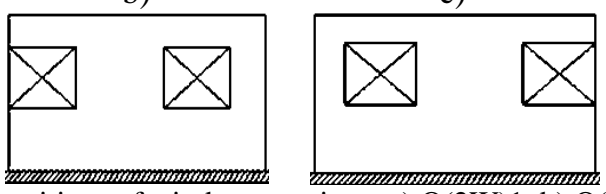

d)

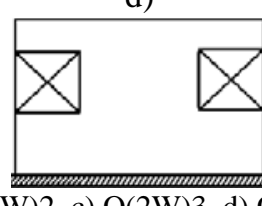

e)

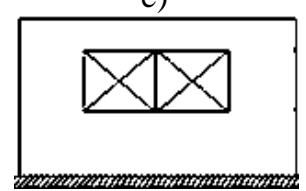

c)

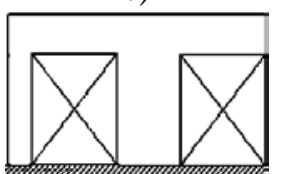

d)

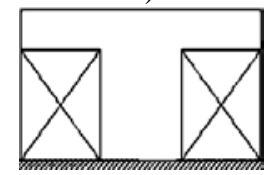

e)

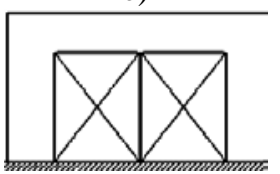

Figure 24 Possible positions of door openings: a) O(2D)1, b) O(2D)2, c) O(2D)3, d) O(2D)4, e) O(2D)5
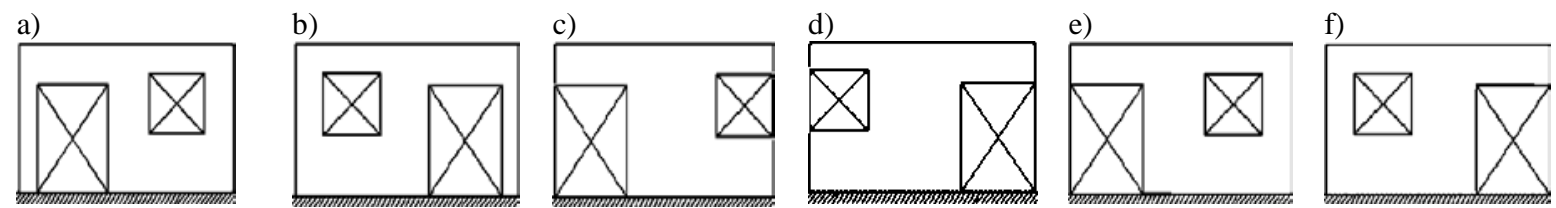

Figure 25 Possible positions of door and window openings: a) O(DW)1, b) O(DW)2, c) O(DW)3, d) O(DW)4, e) $\mathrm{O}(\mathrm{DW}) 5$, f) $\mathrm{O}(\mathrm{DW}) 6$

Considering the results displayed in Table 8, it can be easily concluded that for all opening configurations, moving the openings toward the boundaries increases the initial stiffness and 
lateral strength of the infilled frames. A similar trend was previously pointed out by Asteris [18] in masonry infill walls with variation in window geometry and location. In the present study, moving the two window openings to the nearest point to the enclosure frame (walls $\mathrm{O}(2 \mathrm{~W}) 1$ and $\mathrm{O}(2 \mathrm{~W}) 4$ ) results in an increase in the initial stiffness and lateral strength of about $24 \%$ and $19 \%$, respectively.

In the case of walls with two similar door openings, the movement of these openings toward the frame boundary leads to a maximum increase in initial stiffness and lateral strength of $41 \%$ and $3 \%$, respectively, with values of $30 \%$ and $7 \%$ observed in the case of one window and one door. Such opening movement is also more effective in terms of stiffness in walls with larger opening areas. In contrast, as shown in Figure 26, the opposite is true in terms of the increase in lateral strength caused by moving the openings toward boundaries in the walls, with higher values recorded in walls with lower opening areas. This means that in walls with a high opening percentage (greater than 50\%), moving the openings towards the boundaries does not increase wall lateral strength.

Table 8 Model initial stiffness

\begin{tabular}{|c|c|c|c|c|c|c|c|}
\hline & & \multicolumn{3}{|c|}{ Initial Stiffness (N/mm) } & \multicolumn{3}{|c|}{ Lateral Strength (N) } \\
\hline Wall & A & $\begin{array}{c}\text { Numerical } \\
\text { Results } \\
\text { (N/mm) }\end{array}$ & $\begin{array}{l}\text { Simplified } \\
\text { approach } \\
(\mathrm{N} / \mathbf{m m})\end{array}$ & $\begin{array}{c}\text { Error } \\
(\%)\end{array}$ & $\begin{array}{l}\text { Numerical } \\
\text { Results (N) }\end{array}$ & $\begin{array}{c}\text { Simplified } \\
\text { approach }(\mathbf{N})\end{array}$ & Error (\%) \\
\hline $\mathbf{O}(2 \mathrm{~W}) 1$ & \multirow{4}{*}{0.20} & 28490 & 35150 & 23.4 & 65100 & 75010 & 15.2 \\
\hline $\mathbf{O}(2 W) 3$ & & 32260 & 35150 & 9.0 & 68510 & 75010 & 9.5 \\
\hline $\mathrm{O}(2 W) 4$ & & 35410 & 35150 & 0.7 & 77710 & 75010 & 3.5 \\
\hline $\mathrm{O}(2 \mathrm{~W}) 5$ & & 30240 & 35150 & 16.2 & 66050 & 75010 & 13.6 \\
\hline O(2D)1 & \multirow{4}{*}{0.54} & 12250 & 11410 & -6.9 & 54840 & 51640 & -5.8 \\
\hline $\mathbf{O}(2 \mathrm{D}) 3$ & & 14440 & 11410 & -21.0 & 57060 & 51640 & -9.5 \\
\hline O(2D)4 & & 17250 & 11410 & -33.8 & 56370 & 51640 & -8.4 \\
\hline O(2D)5 & & 15970 & 11410 & -28.5 & 55030 & 51640 & -6.2 \\
\hline $\mathrm{O}(\mathrm{DW}) 2$ & \multirow{3}{*}{0.37} & 19900 & 20360 & 2.3 & 58240 & 58680 & 0.8 \\
\hline O(DW)4 & & 25870 & 20360 & -21.3 & 62240 & 58680 & -5.7 \\
\hline O(DW)6 & & 22770 & 20360 & -10.6 & 59970 & 58680 & -2.1 \\
\hline & & & Average & 15.8 & & & 7.3 \\
\hline
\end{tabular}

The simplified approach developed in the previous section for infills with central openings was used in Table 8 to determine the initial stiffness and lateral strength of infills with typical openings. As the data demonstrate, this approach is able to predict the initial stiffness of models with a central opening with an average error of $16 \%$ (maximum 34\%). For wall lateral strength, average error and maximum error are both reasonable (typically below 10\%). Although the simplified approach can be considered a good method with which to predict the initial stiffness of walls with central openings, it cannot consistently capture the behaviour of models with other typical opening types. For instance, the error produced when predicting the initial stiffness of wall O(2D)4 using the simplified approach was high (about 34\%).

Given the considerable error obtained for the initial stiffness, it was decided to develop an empirical equation to predict this parameter for the models with distinct types of opening at any position. To this end, the initial stiffness of the model with central openings is obtained via equation (3) and a correction based on a position factor, $\alpha$, which takes into account the geometric relations of the individual infill piers:

$$
K=K_{C O} \times \alpha
$$

The position factor, $\alpha$, takes into consideration the relation of stiffness of the different piers and is defined by the following equation, via inverse fitting: 


$$
\alpha=\frac{\sum\left(\frac{b_{i}}{h_{i}}\right)^{1.035}}{\sum\left(\frac{b_{i}}{h_{i}}\right)}+A^{3} \Sigma\left(\frac{b_{i}}{h_{i}}\right)^{2.5}
$$

Here, $b_{i}$ is the width of the piers, $h_{i}$ is height of the openings and $A$ is the total area of the openings (see Figure 27). Table 9 shows that this equation satisfactorily takes into account the changes in opening position (7\% error on average, with a maximum error of $14 \%$ ).

a)

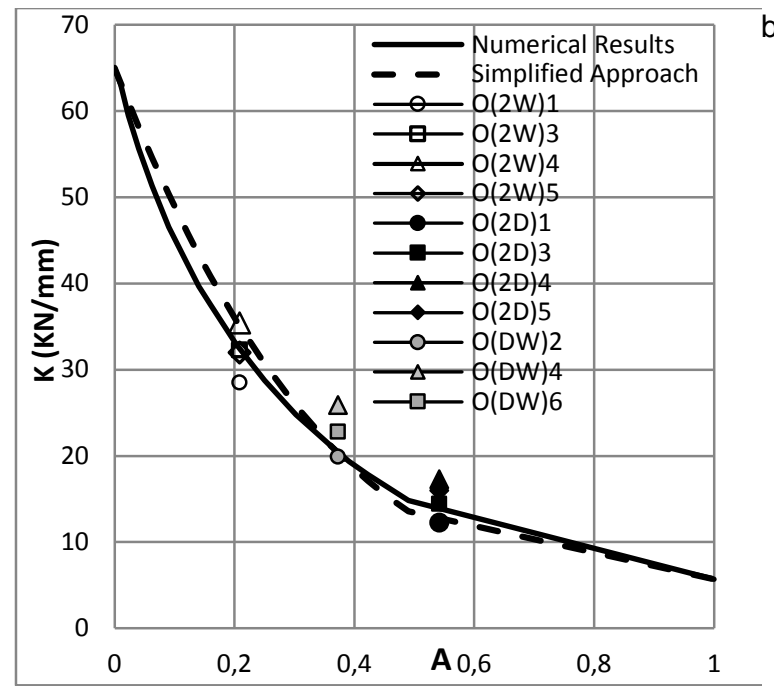

b)

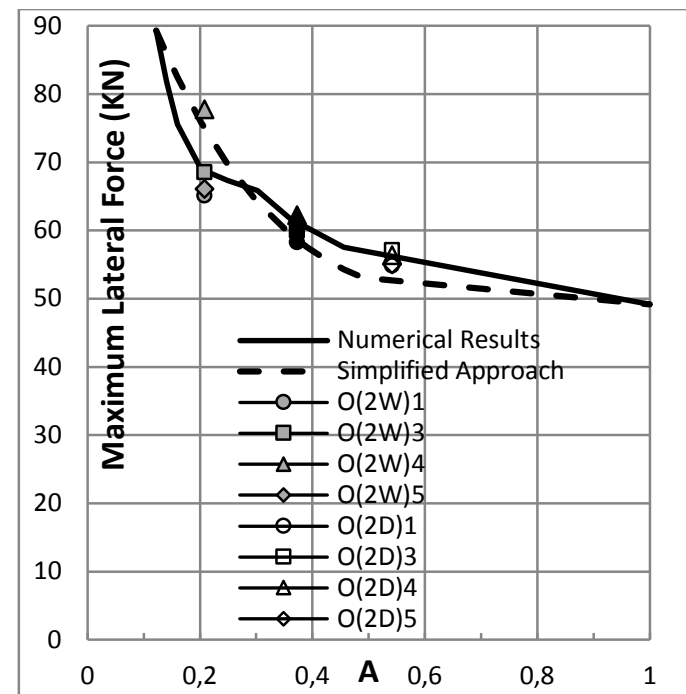

Figure 26 Prediction of key parameters of the in-plane behaviour of walls with different opening configurations; a) initial stiffness and b) lateral strength

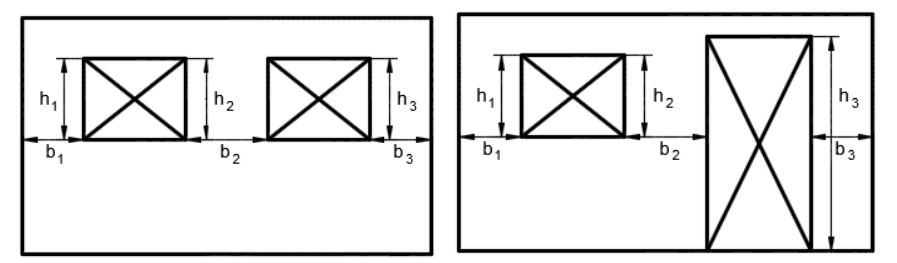

Figure 27 Width and height of piers used for the calculation of equation (7)

\section{Equivalent Width of the Diagonal Strut for Infills with Openings}

In this section the infill with any typical opening is replaced by an equivalent diagonal strut of width "w" with the same initial stiffness. For this purpose, a new numerical model was constructed using four-noded plane stress elements for the RC frame and truss elements for the strut elements. As the initial stiffness was the parameter under evaluation, linear elastic analysis of the model was carried out. Different values for the width of the equivalent diagonal strut were considered in the linear regime in order to investigate how this parameter affects the lateral stiffness of the wall under in-plane loading. According to the results shown in Figure 28 (where $\mathrm{d}$ is the diagonal length of the infill), it is apparent that by increasing the width of the diagonal strut, the initial stiffness of the infilled frame increases linearly, with an $r^{2}$ of 0.9998 . It can thus be concluded that the ratio of the width of the diagonal strut, $w$, to the diagonal length of the masonry infill wall, $d$, ratio $(w / d)$, equals 0.32 , which corresponds to the initial stiffness of the frame with solid masonry infill. This means that the solid masonry infill within the frame modelled in the present paper can be replaced by a diagonal strut of width, $w$, equal to $1.25 \mathrm{~m}$. A range of different equations have similarly been proposed elsewhere to calculate the width of a diagonal strut replacing a solid infill panel without openings [26, 27, 31, 35]. Figure 29 compares the equivalent width of such a diagonal strut obtained here via numerical 
analysis with values given by different equations found in the literature. From this figure it can be observed that the proposed equations generally provide lower values for the width of the equivalent strut than that found here in the numerical analysis, with the value calculated from FEMA 356 [49] being the most conservative.

Table 9 Comparison of empirical equation and numerical results

\begin{tabular}{|c|c|c|c|c|c|c|}
\hline Wall & A & $\begin{array}{c}b_{i} \\
(\mathbf{m})\end{array}$ & $\begin{array}{c}h_{i} \\
(\mathbf{m})\end{array}$ & $\begin{array}{c}K=K_{C O} \times \alpha \\
(\mathbf{N} / \mathbf{m m})\end{array}$ & $\begin{array}{c}\text { Numerical } \\
\text { Results (N/mm) }\end{array}$ & $\begin{array}{c}\text { Error (\%) } \\
\frac{K-\text { Numerical }}{\text { Numerical }} * 100\end{array}$ \\
\hline \multirow{3}{*}{$\mathbf{O}(2 W) 1$} & \multirow{8}{*}{0.2} & 0.6 & 0.68 & \multirow{3}{*}{32260} & \multirow{3}{*}{28490} & \multirow{3}{*}{13.2} \\
\hline & & 0.6 & 0.68 & & & \\
\hline & & 0.48 & 0.68 & & & \\
\hline \multirow{2}{*}{$\mathbf{O}(2 W) 3$} & & 0.48 & 0.68 & \multirow{2}{*}{33580} & \multirow{2}{*}{32260} & \multirow{2}{*}{4.1} \\
\hline & & 1.2 & 0.68 & & & \\
\hline $\mathrm{O}(2 W) 4$ & & 1.68 & 0.68 & 35710 & 35410 & 0.8 \\
\hline \multirow{2}{*}{$\mathrm{O}(2 \mathrm{~W}) 5$} & & 0.84 & 0.68 & \multirow{2}{*}{33140} & \multirow{2}{*}{30240} & \multirow{2}{*}{9.6} \\
\hline & & 0.84 & 0.68 & & & \\
\hline \multirow{3}{*}{$\mathbf{O}(2 D) 1$} & \multirow{8}{*}{0.54} & 0.3 & 1.4 & \multirow{3}{*}{13960} & \multirow{3}{*}{12250} & \multirow{3}{*}{13.9} \\
\hline & & 0.6 & 1.4 & & & \\
\hline & & 0.3 & 1.4 & & & \\
\hline \multirow{2}{*}{$\mathbf{O}(2 D) 3$} & & 0.3 & 1.4 & \multirow{2}{*}{14620} & \multirow{2}{*}{14440} & \multirow{2}{*}{1.2} \\
\hline & & 0.9 & 1.4 & & & \\
\hline O(2D)4 & & 1.2 & 1.4 & 15630 & 17250 & -9.4 \\
\hline \multirow{2}{*}{$\mathrm{O}(2 \mathrm{D}) 5$} & & 0.6 & 1.4 & \multirow{2}{*}{14300} & \multirow{2}{*}{15970} & \multirow{2}{*}{-10.5} \\
\hline & & 0.6 & 1.4 & & & \\
\hline \multirow{3}{*}{$\mathrm{O}(\mathrm{DW}) 2$} & \multirow{6}{*}{0.37} & 0.6 & 0.68 & \multirow{3}{*}{21310} & \multirow{3}{*}{19900} & \multirow{3}{*}{7.1} \\
\hline & & 0.54 & 0.68 & & & \\
\hline & & 0.3 & 1.4 & & & \\
\hline O(DW)4 & & 1.44 & 0.68 & 27490 & 25870 & 6.3 \\
\hline \multirow{2}{*}{ O(DW)6 } & & 0.6 & 0.68 & \multirow{2}{*}{22740} & \multirow{2}{*}{22770} & - 1 \\
\hline & & 0.84 & 0.68 & & & -0.1 \\
\hline & & & & & Average & 6.9 \\
\hline
\end{tabular}

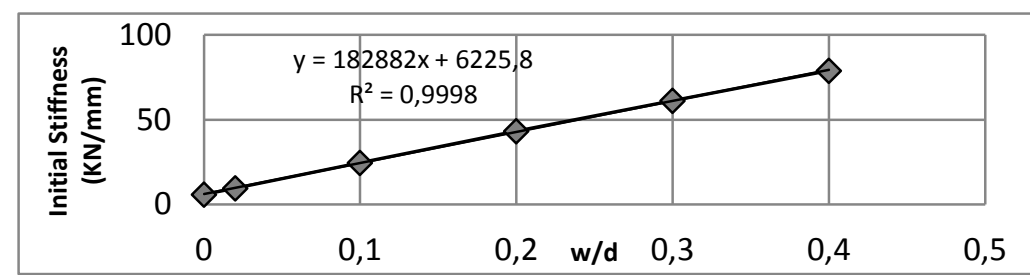

Figure 28 Variation of initial stiffness with width of diagonal strut

The value obtained via the updated Papia, Cavaleri and Fossetti equation [31] is closest to the numerical result obtained here. According to this equation, the equivalent width of the diagonal strut is given by:

$$
\begin{gathered}
{ }_{\text {fill }}=\frac{k \cdot c}{d \cdot z} \frac{1}{\left(\lambda^{*}\right)} \\
k=1+\left(18 \lambda^{*}+200\right) \varepsilon_{V} \\
\varepsilon_{V}=\frac{F_{V}}{2 A_{C} E_{f}}
\end{gathered}
$$




$$
\begin{gathered}
\lambda^{*}=\frac{E_{\text {inf }}}{E_{f r}} \frac{t \cdot h^{\prime}}{A_{\text {col }}}\left(\frac{h^{\prime 2}}{l^{2}}+\frac{1}{4} \frac{A_{\text {col }}}{A_{\text {beam }}} \frac{l^{\prime}}{h^{\prime}}\right) \\
c=0.249-0.0116 v+0.567 v^{2} \\
\beta=0.146+0.0073 v+0.126 v^{2} \\
\left\{\begin{array}{cc}
z=1+0.25(l / h-1) & 1 \leq l / h \leq 1.5 \\
z=1.125 & 1.5<l / h
\end{array}\right.
\end{gathered}
$$

where $w_{\text {fill }}$ is the width of the strut for the solid infilled frame, $l$ is infill length, $h$ is the infill height, $l^{\prime}$ is the frame length between the two column centre lines, $h^{\prime}$ is the frame height between the two beam centre lines, $t$ is the infill thickness, $E_{\text {inf }}$ and $E_{f r}$ are the modulus of elasticity of infill and frame, respectively, $A_{c o l}$ is the column cross-section, $A_{\text {beam }}$ is the beam cross-section and $v$ is the infill Poisson ratio. This formula is used in the following section to predict the equivalent width of the strut. Aimed at obtaining an updated expression of the width of the diagonal strut in order to simulate the presence of openings, the linear variation of initial stiffness with respect to diagonal strut width as shown in Figure 29 results in:

$$
K=\frac{w}{w_{\text {fill }}}\left(K_{\text {fill }}-K_{\text {bare }}\right)+K_{\text {bare }}
$$

where $w$ corresponds to the width of the equivalent strut for an infilled frame with stiffness $K$ and $w_{\text {fill }}$ is the width of the equivalent strut for a solid infilled frame derived from equation (8). Replacing $\mathrm{K}$ in equation (15), and incorporating equation (6) and equation (3), produces:

$$
w=w_{\text {fill }} \cdot \alpha \cdot f(A)+\frac{(\alpha-1) w_{\text {fill }} K_{\text {bare }}}{K_{\text {fill }}-K_{\text {bare }}}
$$

Equation (16) means that a system of infilled frames (with any opening percentage) can be replaced by a frame with an equivalent diagonal strut of width $w$ and the same initial stiffness.

\section{Guidelines for Using the Equivalent Diagonal Strut Method in Practice}

The proposed equation for calculating the equivalent diagonal strut, i.e. equation (16), can be used for practical purposes in multi-storey structures. However, to do so it is also necessary to calculate $K_{\text {fill }}$ and $K_{\text {bare }}$ for each one-bay one-storey frame inside the structure. Obtaining $w_{\text {fill }}$ from equation (8), which is related only to the geometry of the infilled frame, will lead to the calculation of $K_{\text {fill }}$ for each one-bay one-storey frame, using the following equation proposed by Mainstone [50]:

$$
K_{\text {fill }}=\frac{E_{\text {inf }} w_{\text {fill }} t}{\sqrt{l^{\prime 2}+h^{\prime 2}}} \cos ^{2}(\theta)
$$

where $\theta$ is the angle of the diagonal to the horizontal (degrees). Bazan and Meli [51] proposed a dimensionless parameter, $\beta$, which evaluates the relative stiffness of the RC frame to the infilled panel, as given by:

$$
\beta=\frac{E_{C} A_{C}}{G_{i} A_{i}}
$$


where $E_{c}$ is the modulus of column elasticity, $A_{c}$ is the gross area of the column, $G_{i}$ is the shear modulus of the infill and $A_{i}$ is the area of the masonry panel in the horizontal plane. Once the stiffness of the solid infill and bare frame are calculated, i.e. $K_{\text {fill }}$ and $K_{\text {bare }}$, respectively, these parameters can be replaced in equation (16) for the calculation of the width of the equivalent diagonal strut for each one-bay one-storey frame inside the multi-storey structure. To calculate the lateral strength of the one-bay one-storey infilled frame with any type of opening configuration, it is also necessary to determine the strength of the infill, $F_{\text {fill }}$, and of the bare frame, $F_{\text {bare }}$, separately.

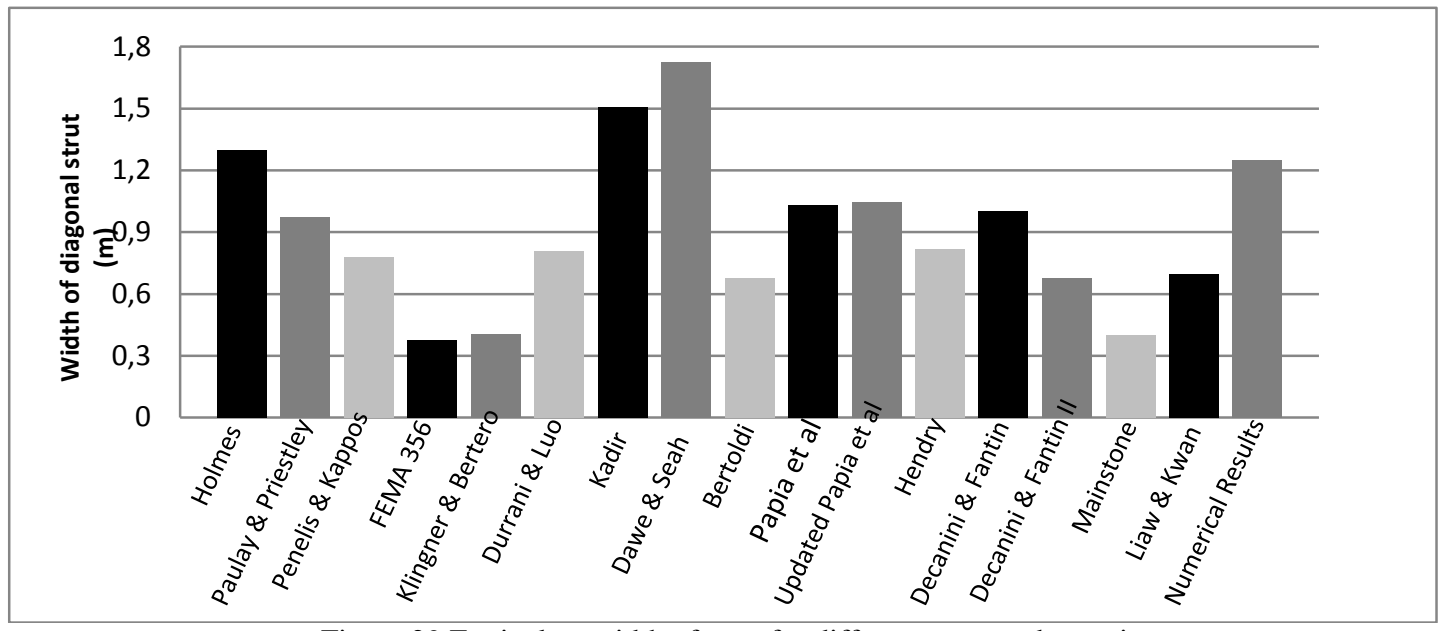

Figure 29 Equivalent width of strut for different proposed equations

The lateral resistance of the bare frame, $F_{\text {bare }}$, can be calculated as:

$$
F_{\text {bare }}=\frac{4 M_{p}}{h^{\prime}}
$$

where $M_{p}$ is the plastic moment of the column cross-section [52]. The lateral strength of the infilled frame is calculated based on the equation proposed by Stafford Smith and Coull [53]:

$$
F_{\text {fill }}=f_{m}^{\prime} t \frac{\pi}{2} \sqrt[4]{\frac{4 E_{c} I_{c} h_{i}}{E_{i} t}}
$$

where $f_{m}^{\prime}$ is the compressive strength of masonry in the panel, $E_{c}$ and $I_{c}$ are the column modulus of elasticity and moment of inertia, respectively, $t$ is the thickness of the infill and $E_{i}$ is the modulus of elasticity of the infill panel. Based on the results of equations (19) and (20), the lateral strength of the infilled panel with any type of opening configuration can be calculated via equation (5). The equivalent stress of the strut for infills with any type of opening in the numerical analysis is calculated as:

$$
\sigma_{s}=\frac{F_{c o}}{t w \cos \theta}
$$

Aimed at validating the equations proposed herein with which to calculate the width of the diagonal strut describing the behaviour of a masonry-infilled RC frame with any opening configuration, three different numerical models were built, as shown in Figure 30, corresponding to different numbers of floors and a random distribution of openings in the infills. The same frames were also modelled considering the masonry infills replaced by diagonal struts whose width is calculated via equation (16). A comparison was made in terms 
of initial stiffness and lateral strength between both models (Table 10). Analysis of the results reveals that the numerical model of the equivalent diagonal strut and adopting the proposed formulation, can satisfactorily predict the initial stiffness and lateral strength of multi-storey infilled frames with an error lower than $14 \%$. It is considered that these results validate the ability of equation (16) in predicting the initial stiffness and lateral strength of multi-storey infilled frames with any distribution of openings in the infills.
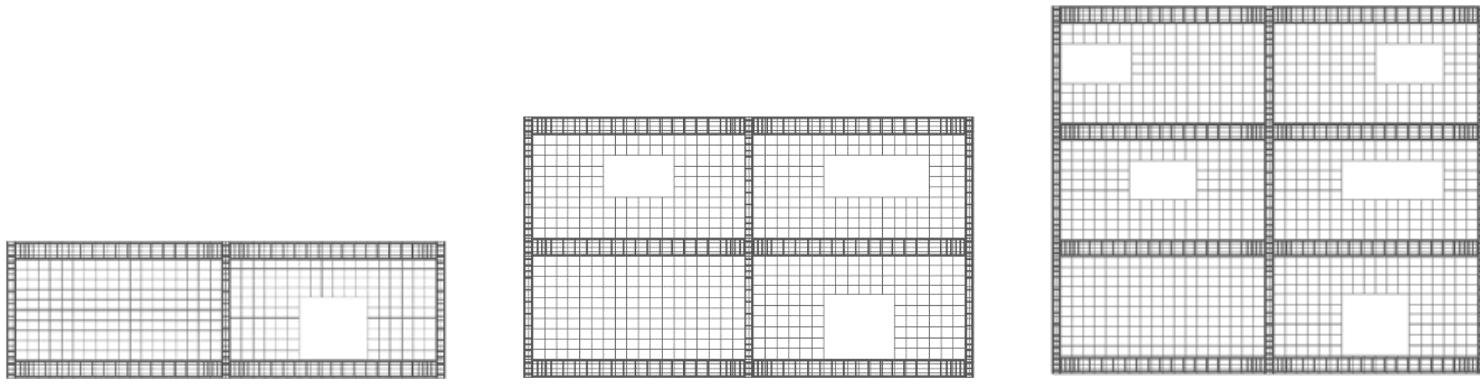

Figure 30 Numerical modelling of three multi-storey structures in DIANA

Table 10 Comparison between the analytical results of finite element modelling and the equivalent diagonal strut model

\begin{tabular}{|c|c|c|c|c|c|c|}
\hline & \multicolumn{2}{|c|}{ Finite element modelling } & \multicolumn{2}{|c|}{$\begin{array}{c}\text { Equivalent diagonal strut } \\
\text { model }\end{array}$} & \multirow{2}{*}{$\begin{array}{c}\text { Error in } \\
\text { Stiffness } \\
\quad(\%)\end{array}$} & \multirow{2}{*}{$\begin{array}{c}\text { Error in } \\
\text { Strength } \\
\quad(\%)\end{array}$} \\
\hline Model & $\begin{array}{c}\text { Initial } \\
\text { Stiffness } \\
(\mathrm{KN} / \mathbf{m m})\end{array}$ & $\begin{array}{c}\text { Lateral } \\
\text { Strength } \\
(\mathrm{KN})\end{array}$ & $\begin{array}{c}\text { Initial } \\
\text { Stiffness } \\
(\mathrm{KN} / \mathbf{m m})\end{array}$ & $\begin{array}{c}\text { Lateral } \\
\text { Strength } \\
(\mathrm{KN})\end{array}$ & & \\
\hline One-storey & 119.5 & 170.4 & 107 & 177.9 & 10.5 & -4.4 \\
\hline Two-storey & 54.5 & 177.1 & 47.8 & 201.8 & 12.3 & -13.9 \\
\hline $\begin{array}{l}\text { Three- } \\
\text { storey }\end{array}$ & 35.8 & 181.9 & 31.2 & 189.7 & 12.8 & -4.3 \\
\hline
\end{tabular}

\section{Conclusions}

In this work a numerical model of a one-bay and one-storey masonry-infilled reinforced concrete frame was modelled using the DIANA software program and calibrated based on the results obtained from experimental in-plane cyclic tests. Subsequently, an extensive parametric numerical analysis was carried out to investigate the influence of different opening types and configurations on the in-plane behaviour of the infilled frames. It should be noted that the results presented here relate only to strong RC frames with weak masonry infills, with the following conclusions reached:

1. The presence of openings decreases the initial stiffness of the infilled frames. An increase of the opening area decreases the initial stiffness of the infilled frame, with the rate of this decrease being greater for a lower opening percentage and vice versa.

2. Increasing the opening area reduces the lateral strength of infilled frames, with the rate of this decrease being greater for smaller opening areas than for larger opening areas.

3. Increasing the opening area in the infill results in the maximum lateral resistance of the infilled frame being obtained at larger displacements.

4. Equations derived from parametric numerical simulation can satisfactorily predict the initial stiffness and lateral strength of the masonry-infilled reinforced concrete frames with central openings.

5. For infilled frames with typical openings (window and door openings with different locations in the walls), an empirical formula was developed taking into account the position of the openings. This formula can satisfactorily predict the initial stiffness of the infilled frames.

6. It was observed that an increase of the width of the diagonal strut increases the initial stiffness of the infilled frames linearly. It was concluded that infill panels with any type of 
opening can be replaced by an equivalent strut of width $W$, with a proposal made for the calculation of the width of the diagonal strut in the case of masonry infill with openings.

\section{Acknowledgements}

The authors would like to acknowledge the Portuguese Foundation for Science and Technology (FCT) for funding the research project RetroInf - Developing innovative solutions for seismic retrofitting of masonry infill walls (PTDC/ECM/122347/2010).

\section{References:}

[1] DolŠEk M, Fajfar P. Soft Storey Effects in Uniformly Infilled Reinforced Concrete Frames. Journal of Earthquake Engineering. 2001;5:1-12.

[2] Kusumastuti D. Report on the West Sumatra Earthquake of September 30, 2009. MCEER Bulletin; 2010.

[3] Guevara LT, García LE. INTERNATIONAL NETWORK FOR THE DESIGN OF EARTHQUAKE RESILIENT CITIES (INDERC).

[4] Pereira MFP. Avaliação do desempenho das envolventes dos edifícios face à acção dos sismos: Universidade do Minho; 2013.

[5] Mehrabi AB. Behavior of masonry-infilled reinforced concrete frames subjected to lateral loadings [Ph. D.]: University of Colorado; 1994.

[6] Mosalam K, White R, Gergely P. Static Response of Infilled Frames Using Quasi-Static Experimentation. Journal of Structural Engineering. 1997;123:1462-4169.

[7] Dawe JL, Seah CK. Behaviour of masonry infilled steel frames. Canadian Journal of Civil Engineering. 1989;16:865-76.

[8] Hashemi A, Mosalam KM. Shake-table experiment on reinforced concrete structure containing masonry infill wall. Earthquake Engineering \& Structural Dynamics. 2006;35:1827-52.

[9] Shing PB, Mehrabi AB. Behaviour and analysis of masonry-infilled frames. Progress in Structural Engineering and Materials. 2002;4:320-31.

[10] Crisafulli F. Seismic Behavior of Reinforced Concrete Structures with Masonry Infills. New Zealand: University of Canterbury; 1997.

[11] Kakaletsis DJ, Karayannis CG. Influence of Masonry Strength and Openings on Infilled R/C Frames Under Cycling Loading. Journal of Earthquake Engineering. 2008;12:197-221.

[12] Chrysostomou CZ, Asteris PG. On the in-plane properties and capacities of infilled frames. Engineering Structures. 2012;41:385-402.

[13] Kakaletsis DJ. Masonry infills with window openings and influence on reinforced concrete frame constructions. Seventh International Conference on Earthquake Resistant Engineering Structures. Cyprus; 2009.

[14] Mallick DV, Garg RP. Effect of openings on the lateral stiffness of infilled frames. Proceedings-Institution of Civil Engineers. 1971;193-209.

[15] Tasnimi AA, Mohebkhah A. Investigation on the behavior of brick-infilled steel frames with openings, experimental and analytical approaches. Engineering Structures. 2011;33:968-80.

[16] Surendran S, Kaushik HB. Masonry infill RC frames with openings: review of in-plane lateral load behaviour and modeling approaches. The Open Construction and Building Technology Journal. 2012;6:126-54.

[17] Asteris PG, Giannopoulos IP, Chrysostomou CZ. Modeling of Infilled Frames With Openings. The Open Construction and Building Technology Journal. 2012;6(Suppl 1-M6):81-91.

[18] Asteris P. Lateral Stiffness of Brick Masonry Infilled Plane Frames. Journal of Structural Engineering. 2003;129:1071-9.

[19] Giannakas A, Patronis D, Fardis M. The influence of the position and the size of openings to the elastic rigidity of infill walls. 8th Hellenic Concrete Conf. Xanthi, Kavala, Greece; 1987. p. 49-56.

[20] Lourenço PB. Computational strategies for masonry structures [Diss , Technische Universiteit Delft, 1996]. Delft: Delft University Press; 1996.

[21] Mosalam KM, Gergely P, White RN, Zawilinski D. The Behaviour of Frames with Concrete Block Infill Walls. Proceedings of the First Egyptian Conference on Earthquake Engineering; 1993. p. 283-92.

[22] Asteris PG, Cotsovos DM, Chrysostomou CZ, Mohebkhah A, Al-Chaar GK. Mathematical micromodeling of infilled frames: State of the art. Engineering Structures. 2013;56:1905-21.

[23] Asteris PG, Antoniou ST, Sophianopoulos DS, Chrysostomou CZ. Mathematical Macro-Modeling of Infilled Frames: State of the Art. Journal of Structural Engineering. 2011;137(12).

[24] Crisafulli FJ, Carr AJ. Proposed macro-model for the analysis of infilled frame structures. Bulletin of the New Zealand society for earthquake engineering. 2007;40. 
[25] Smyrou E, Blandon C, Antoniou S, Pinho R, Crisafulli F. Implementation and verification of a masonry panel model for nonlinear dynamic analysis of infilled RC frames. Bull Earthquake Eng. 2011;9:1519-34.

[26] Holmes M. Steel Frames with Brickwork and Concrete Infilling. ICE Proceedings; 1961. p. 473-8.

[27] Cavaleri L, Papia M. A new dynamic identification technique: application to the evaluation of the equivalent strut for infilled frames. Engineering Structures. 2003;25:889-901.

[28] Decanini LD, Fantin GE. Modelos simplificados de la mamposteria incluida en porticos. Caracteristicas de rigidezy resistencia lateral en estado limite. Jornadas Argentinas de Ingenieria Estructural. Buenos Aires, Argentina; 1986. p. 817-36.

[29] Amato G, Fossetti M, Cavaleri L, Papia M. An Updated Model of Equivalent Diagonal Strut for Infill Panels Eurocode 8 Perspectives from the Italian Standpoint Workshop. Doppiavoce, Napoli, Italy; 2009. p. 119-28.

[30] Bertoldi SH, Decanini LD, Gavarini C. Telai tamponati soggetti ad azioni sismiche, un modello semplificato: confronto sperimentale e numeric. Atti del 6 Convegno Nazionale ANIDIS; 1993. p. 815-24.

[31] Dawe JL, Seah CK. Analysis of concrete masonry infilled steel frames subjected to in-plane loads. Proceedings of the 5th Canadian Masonry Symposium. Vancouver; 1989. p. 329-40.

[32] Durrani AJ, Luo YH. Seismic retrofit of flat-slab buildings with masonry infills. NCEER workshop on seismic response in Masonry Infills; 1994.

[33] Hendry AW. Structural masonry. London: MacMillan Education Ltd.; 1990.

[34] Kadir MRA. The structural behaviour of masonry infill panels in framed Structures: University of Edinburgh; 1974.

[35] Mainstone R. Summary of paper 7360. ON THE STIFFNESS AND STRENGTHS OF INFILLED FRAMES. ICE Proceedings; 1971.

[36] Smith BS. Behaviour of square infilled frames. Proceedings of the American Society of Civil Engineers, Journal of Structural Division. 1966;92:381-403.

[37] Smith BS, Carter C. A method of analysis for infilled frames. ICE Proceedings; 1969. p. 31-48.

[38] Te-Chang L, Kwok-Hung K. Nonlinear behaviour of non-integral infilled frames. Computers \& Structures. 1984;18:551-60.

[39] Uva G, Raffaele D, Porco F, Fiore A. On the role of equivalent strut models in the seismic assessment of infilled RC buildings. Engineering Structures. 2012;42:83-94.

[40] Smyrou E. Implementation and verification of Masonry panel model for nonlinear dynamic analysis of Infilled RC frames: European School for Advanced Studies in Reduction of Seismic Risk (ROSE School); 2006.

[41] Blandon-Uribe CA. Implementation of an infill masonry model for seismic assessment of existing buildings: European School for Advanced Studies in Reduction of Seismic Risk (ROSE School). 2005.

[42] Soroushian P, Obaseki K, Choi K. Nonlinear Modeling and Seismic Analysis of Masonry Shear Walls. Journal of Structural Engineering. 1988;114:1106-19.

[43] 8 E. Design of Structures for Earthquake Resistance. December 2003.

[44] Vasconcelos G, Lourenço P. In-Plane Experimental Behavior of Stone Masonry Walls under Cyclic Loading. Journal of Structural Engineering. 2009;135:1269-77.

[45] CEST. DIANA User's Manual, Release 9.3

[46] Lourenço PB, Rots JG. Multisurface Interface Model for Analysis of Masonry Structures. Journal of Engineering Mechanics. 1997;123:660-8.

[47] Lourenço PB. Analysis of Masonry Structures with Interface elements; Theory and Applications. In: TNO Building and Construction Research C.M., editor; 1994.

[48] Furtado A, Costa C, Rodrigues H, Arêde A. Characterization of structural characteristics of Portuguese buildings with masonry infill walls stock. 9th International Masonry Conference. University of Minho, Guimarães , Portugal; 2014.

[49] Kyriakides MA. Seismec Retrofit of Unreinforced Masonry Infills in Non-ductile Reinforced Concrete Frames Using Engineered Cementitious Composites. Stanford University; 2011.

[50] Mainstone RJ. On the stiffness and strength of infilled frames. Proceeding of Institution of Civil Engineers (ICE). 1971;Supplement (IV):57-90.

[51] Bazan E, Meli R. Seismic Analysis of Structures with Masonry Walls. Proceeding of the Seventh World Conference on Earthquake Engineering. Istanbul, Turkey; 1980. p. 633-40.

[52] Dubey SKD, Kute SY. Experimental investigation on the ultimate strength of partially infilled and steel-braced reinforced concrete frames. International Journal of Advanced Structural Engineering. 2013;5.

[53] Stafford Smith B, Coull A. Tall building structures: Analysis and design. New York: Wiley; 1991. 